\title{
Pedagogical CuRricula and Educational Media: THE MALIGNANCY OF SAFFRONISED OTHERISATION IN INDIA
}

\section{Titas Biswas*}

\begin{abstract}
Saffronisation, a neologism that is derived from the saffron robes worn in particular by holy Hindu men, is used to denote the conflation of linguistic, semiotic and political actions taken by the far-right Hindu nationalist brotherhood in India to mechanically alter Indian history so that it resonates with the rest of the Hindu nationalist propaganda and policymaking. The process of Saffronisation, when coupled with westernised pedagogical curricula, has been inculcated within and beyond the periphery of educational institutions since the early twentieth century. This paper explores the impact of Saffronisation as a socio-political movement on educational institutions, the changes that have been made in textbooks in the recent times and in a holistic sense, attempts to analyse the effects of a neo-Fascist governance on schooling and how it affects students hailing from backgrounds that have been marginalised for generations. It is also an exploration of the role of the saffron propaganda in enabling otherisation of non-Hindu identities in higher education institutions..
\end{abstract}

Keywords: Education, Curricula, Hindutva, Institution, Pedagogy, Saffronisation

* Titas Biswas, Department of Sociology, Jadavpur University, India;

e-mail: titas.biswas@1947partitionarchive.org | ORCID: https://orcid.org/0000-0002-0462-4393 
A Brief History of Saffronisation

Hindu nationalism is an ideology that seeks to mould nationalism in accordance with Hindu religious values and sentiments. Hindu nationalist ideologies, promoted by the Sangh Parivar (family of Hindu nationalist organisations) are often fundamental and rooted in vehement otherisation of non-Hindu religious identities. The Sangh Parivar, which is a conglomeration of political, social, cultural, educational, youth, labour and women's organisations is a leading proponent of a philosophical vision that argues for a future that is solely Hindu, and wants to confer upon India's minorities, particularly the Muslims, a secondary status of citizenship (Ambikar 2012).

The Bharatiya Janata Party (BJP), its parent organisation that has spawned off several other organisations of its kind called the Rāstrīya Svayamsevak Sangh (RSS), the Shiv Sena, Bajrang Dal and the student's organisation Akhil Bharatiya Vidyarthi Parishad (ABVP) are some of the well-known names in this regard. The political neologism 'Saffronisation', which derives from the saffron robes worn by holy Hindu men, refers to linguistic and semiotic actions of right-wing nationalists in enforcing a reversion to the ancient Hindu way of life. The neologism becomes a metaphor for the Sangh Parivar, personified as a being who goes unabated in its effort to spread saffron propaganda as a form of ideological invasion (See: Bhatia 2015).

The Sangh Parivar consists of a number of organisations, often working regionally within India's federal structure. Saffronisation has been used to denote changes incorporated within educational curricula to encourage an intricate understanding of Hindu identities, juxtaposed against the otherised foreign invaders - the Muslims and the Christians.

Saffronisation, as a political movement, has then been associated with historical, socio-cultural, linguistic and most importantly, an un- 
scholarly and biased re-interpretation of India's ancient religious history as well as the medieval and modern accounts of annexation and proselytisation. Although the roots of organisational Hindu fundamentalism is a much older discourse, the dichotomous operation of the Westernised education system coupled with internalisation of discrimination brought upon students belonging to minority and lower caste communities, pedagogical and institutional embodiment of conflict rooted in casteism and religious fundamentalism is a little more than a century old.

More often than not, Saffronisation has been looked at as a procedural propaganda that results in the radicalisation of Hindus, one that seems to be proliferative on the basis of vehement otherisation of nonHindu identities. Although as part of a transnational political scheme, it is yet obscure what the larger motives of the far-right, Hindutvavadi ${ }^{1}$ (Hindu nationalists) conglomerate might be (Casolari 2000; Bose 2008), a greater emphasis on a parallel agenda to highlight and promote cultural Hinduisation that claims to be social, yet apolitical (Antidote to Self-Oblivion 2012) is a strategy that the paramilitary organisation Rāsțīya Svayamsevak Sangh ${ }^{2}$ (RSS), considered the parent organisation of the Bharatiya Janata Party (BJP), has adopted since its consolidation in 1925 .

The RSS plays a crucial role in the cultural conditioning and reification of the neo-Hindu identity, particularly among its adolescent and young adult members. The 'Vision and Mission' section provided on the official website of RSS consists of the following words quoted by K.B. Hedgewar:

\footnotetext{
' Hindutva in Hindi means 'Hinduness' and 'vaad refers to 'ism' or 'doctrine'. 'Hindutvavaad is a blend of the two words referring to the ideology of Hindu nationalism.

2 'Rāșt rīya', derived from 'Rāșțra (state)' is an adjective meaning 'of the state' or statist. Svayamsevak is a blend word consisting of 'svayam' meaning 'self' and 'sevak referring to 'one who serves'. Svayamsevak refers to a 'volunteer' - one who offers service (seva) by himself (svayam), as opposed to a person who offers service because she/he is forced to/paid to offer this service.
} 
"The Hindu culture is the life-breath of Hindustan3. It is therefore clear that if Hindustan is to be protected, we should first nourish the Hindu culture. If the Hindu culture perishes in Hindustan itself, and if the Hindu society ceases to exist, it will hardly be appropriate to refer to the mere geographical entity that remains as Hindustan. Mere geographical lumps do not make a nation. The entire society should be in such a vigilant and organised condition that no one would dare to cast an evil eye on any of our points of honour. Strength, it should be remembered, comes only through organization. It is therefore the duty of every Hindu to do his best to consolidate the Hindu society. The Sangh is just carrying out this supreme task. The present fate of the country cannot be changed unless lakhs of young men dedicate their entire lifetime for that cause. To mould the minds of our youth towards that end is the supreme aim of the Sangh (RSS: The Mission 2012).

Although RSS denies accounts of direct electoral political involvement, and continues to train its members by subjecting them to a manipulated account of Indian history and politics, almost all BJP leaders have been associated with the RSS at some point in their lives. The RSS can rather bluntly be portrayed as a paramilitary organisation (Anderson 1972).

Its members are often identifiable by the khaki (later white) shirt and khaki pants, which resembles a uniform. Despite this, the organisation has managed to embody within its holistic being apparently harmless rituals, such as that of distributing prasād ${ }^{4}$ after $P \bar{u} j \bar{a}^{5}$ and wearing a tilak ${ }^{6}$ on the forehead, which have now become symbols and constitute the performative aspect of a Hinduised way of life internationally.

\footnotetext{
3 Hindustan is derived from the Persian word 'Hind $\vec{u}$ and the Sanskrit word 'Sindhu'. In middle Persian, the suffix '-stān' was added, indicative of a country or region, forming the present word Hindūstān.

4 ' Prasād refers to food offerings served after worship or Puja that are considered to be holy or sacred. It is a Hindu ritual that varies regionally, and the food served might be both vegetarian and non-vegetarian. Typically in the cow belt and some south Indian states, the concept of vegetarian prasād has been propagated by people belonging to the upper castes.

5 Püjāis a Hindi word used to refer to the ritual of worshipping deities.

6 ' Tilak is a mark that is worn on the face, chest or hand with sandalwood, vermillion or other condiments after worship or Puja and symbolises power, knowledge, and perseverance among other spiritual qualities.
} 
The RSS, despite expanding and annexing its ideological battleground on a brand of politics largely based on hatred maintains a spiritual image that glorifies Hindu familial rituals such as 'Gurudakșină’ where the dharmaguru (supreme spiritual leader) blesses his disciples or the lighting of the holy pyre which is believed to enhance wealth and prosperity. Most of these rituals are practised by Hindu families, particularly hailing from the Hindi belt region 7 of India. Several RSS veterans are found to have joined the organisation as children in order to realise the importance of discipline early in life.

The earliest notions of curricula can be traced back to the akharas, or gymnasiums, where paramilitary activities and martial arts were learned and performed. These sections, however were reserved for men while the women in the organisation would operate within the samitis, and learn self-discipline but at the same time, also realise the importance of the being an obedient, sanskari (cultured) Hindu woman, preferably one who conforms to the command of the patriarchs who control the average orthodox, fundamental Indian Hindu family (Interviewee NV62EX and NOB6E3, 2020 ${ }^{8}$ ).

Incidentally, the RSS was inspired by the mechanism in which Boy Scout groups operated. When it was formed in Nagpur, present day Maharashtra, its operation initially remained constrained within the limits of the akharas (wrestling grounds). The true political motives of the RSS till date remain largely unknown, even to the rank holders within the organisation (Casolari 2000). As for what is known, besides acting as a socio-cultural backup for the electorally political Bharatiya Janata Party (BJP), the RSS has been involved in enabling students and young adults to subject themselves to the discipline visible within military and/or paramilitary troupes (Tewary 2018).

\footnotetext{
7 The Hindi belt region is the north and central region of India where varied dialects of Hindi are spoken as the mother tongues.

8 Oral history interviews of interviewee NV62 EX and NOB6E3 conducted by Titas Biswas (18 th and $24^{\text {th }}$ July, 2020), The 1947 Partition Archive.
} 
With a thriving membership count of around six million, the RSS has been rather successful in instilling in the neo-liberal Hindu mind an undebated conformity to the often manipulated accounts of the ancient religious scriptures, and an undisputed submission to the constructed idea of a golden Vedic period before India had been plagued by "foreign" invasion led by Muslims or Christians. In this imagined era, the subcontinent had progressed because of the physical, social and spiritual wealth that it had amassed, rooted in the Hindu embodiment of its being. The Akhil Bharatiya Vidyarthi Parishad (ABVP), an offshoot of the RSS, claims to be the largest student union in India with a membership of approximately three million (Jaffrelot 1996: 127; M.N., P. 2016).

B.S. Moonje, a Maharashtrian Brahmin and a Sanskrit scholar was inspired by the fascist youth organisations in Italy, where he had travelled to meet Mussolini in person and garner first-hand knowledge about the method of fascist organisation among young adults. He later insisted on a number of structural changes within the RSS and had been keen on modelling schools based on the imprint of the Italian paramilitary organisations he had visited during his stay, and perhaps the sporadic visits he is known to have paid to British and French military schools, institutions and arms factories.

Although most of these schools were similar to ordinary secondary schools, Moonje emphasised on having made programmes in physical exercises, indigenous martial arts, rifle practice and the art of modern warfare elementary under the guidance of trained teachers. It was also believed that the inclusion of moral teachings based on the so called Indian sacred epics, namely the Rāmāyaṇam and Mahābhārata amongst other devotional Hindu literature would result in the emergence of a complete, self-disciplined Hindu individual (See: Casolari 2011). K.B Hedgewar, the man deemed as the "founder of the RSS" was a disciple of Moonje (Baker 1979). 
A Maharashtrian Brahmin, Dr Balkrishna Shivram Moonje was Indian National Congress (INC) leader Bal Gangadhar Tilak's most important political associate in the Nagpur region of the Central Provinces in the first two decades of the twentieth century, and for much of the 1920 s he had been a prominent name in Congress politics on the allIndia stage. Through his participation in Madan Mohan Malaviya's Congress Nationalist Party, Moonje continued to intervene in the politics of the Indian National Congress, but by 1936 he had made the Hindū Mahāsabhā his principal political arena for almost a decade (Meadowcroft 2006: 11). It has been speculated that it had been founded as an organisation as a reactionary measure to the formation of the Muslim league in 1906 (Bapu 2013: 16). K.B. Hedgewar, who became Mahāsabhā general secretary before founding the RSS in 1925, had at first been in Congress politics and elected to the Central Provinces Congress Committee as its joint secretary. He quit the Congress over its support for the Khilafat movement ${ }^{9}$ in 1920-1921 (Ibidem: 37).

Moonje had once remarked, “...any money spent on untouchables is like feeding a garden-serpent with milk. We must leave the untouchables most severely to themselves" (Meadowcroft 2006: 9). The exclusionary politics of segregating the Dalits, cornering them in terms of resources both material and social and thus otherising the Dalit identity in everyday social life has been a characteristic feature of the uppercaste dominated far right Hindu nationalist organisations in India. The one reason that they often refrained from excluding the Dalits from within the realm of Hindutva might have been to simply prevent proselytisation. Prevention of proselytisation has been one of the main motives of almost all organisations constituting the Sangh Parivar.

${ }^{9}$ The Khilafatmovement was a pan-Islamist movement initially launched by Indian Muslims to restore the caliph of the Ottoman caliphate after the Treaty of Sèvres had been imposed upon the Ottoman Empire after the First World War. 


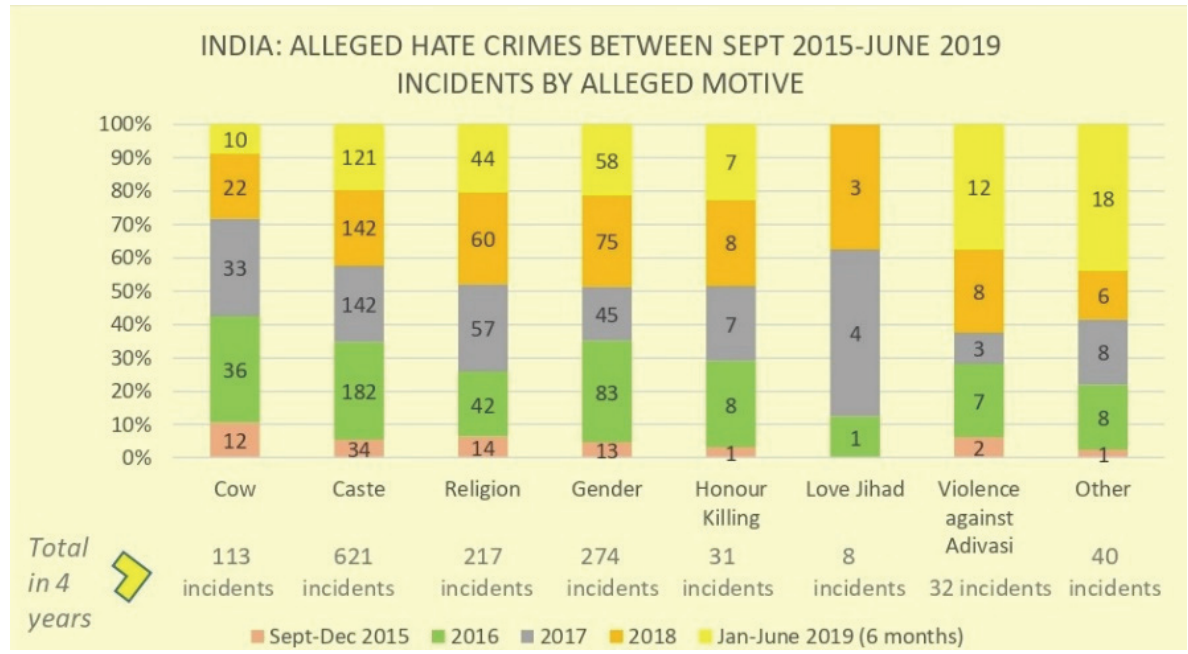

Note. Reproduced from 'Halt the Hate' (Amnesty International 2019), an interactive website initiative undertaken by the Amnesty International that documents reports of alleged hate crimes committed in India.

The over-representation of Maharashtrian Brahmins within the RSS (Jaffrelot 1996: 49) and the dominance of pervasive casteism especially in the states that constitute the Hindi belt might not be entirely unconnected. Although the RSS itself does support claims of equality, and one of the most important figures within the RSS, Madhav Sadashiv Golwalkar ${ }^{10}$ himself was in favour of a hierarchy less concerned with caste and more concerned with a brand of militant Hindutva that was inspired by the Nazi method of organisation in opposition to the non-Hindus, the caste hierarchies that continue to operate within the Sangh Parivar prove otherwise. Even several decades later, the number of reported hate crimes committed against Dalits ${ }^{11}$, particularly after the re-

\footnotetext{
${ }^{10}$ Madhav Sadashiv Golwalkar, a Maharashtrian Brahmin, and the student and successor of Hedgewar as the sarsangcalak of the RSS, was an important figure within the RSS who consolidated it as one of the most important political organisations in India over a period of thirty years, raising its membership from 100,000 to over a million. He also ensured that the Hindu nationalist family of organisations, popularly referred to as the Sangh Parivar, operated in a pan-Indian fashion (Goyal 1979: 96).

" 'Dalit is a Hindi word derived from Sanskrit 'Dalitä meaning "oppressed" or "broken people"
} 
election of the National Democratic Alliance (NDA) coalition ${ }^{12}$ in the national election in 2014, is maximum, judging by motive.

The Amnesty International surveyed the nature of the number of crimes that have been committed against representatives of religious minorities or people belonging to the lower castes after the NDA alliance was elected in 2014. The nature of these crimes is associated with the public propaganda that the BJP had vested their elections upon nationwide inclusive of lynching based on beef eating, caste based atrocities, attacks on Muslims, hate crimes committed on Muslim and Dalit women, honour killing ${ }^{13}$, love jihad ${ }^{14}$ and violence against the scheduled tribes or Adivasis. Economist Deepankar Basu linked the massive electoral victory of the BJP in 2014 to a $300 \%$ increase in anti-minority hate crimes (Basu 2019a; Idem 2019b).

Heil Hindutva: Archival Evidence of the Advent of the RSS and Communication with the Erstwhile Fascist Regimes

The evolution of the RSS, has been historically associated with other fascist organisations, particularly the German Nazi regime and Mussolini's Italy. The organicist essence that remained subsumed in its becoming is not a recent construction and the notions of immense authoritarian control, a particular liking for strict discipline, and vehement otherisation as well as hate crimes committed against non-Hindu, minority communities in India has been a characteristic feature of the Sangh Parivar that perhaps goes back at least to the early twentieth century.

Vinayak Damodar Savarkar was the President of the Hindu Mahāsa$b h \bar{a}$ during the Second World War. In 1938, the newspaper Völkischer

\footnotetext{
${ }^{12}$ The National Democratic Coalition (NDA) is a political alliance in India consisting of right and far-right political parties and organisations, led by the Bharatiya Janata Party (BJP).

13 'Honour Killing' refers to the incidents where one's own kin is involved in the murder of member(s) who have been involved in inter-religious or inter-caste marital or sexual bonding.

14 "Jihäd is an Urdu word with Arabic roots meaning "struggle" or "war". 'Love Jihād', is a phrase used by Hindu fundamentalists to refer to compelled conversion of a woman or man involved in a relationship, marital or otherwise, into Islam.
} 
Beobachter ${ }^{15}$ published Savarkar's views on the Sudetenland issue wherein the Hindu Sangathanists ${ }^{16}$ had undisputed support for uniting the Austrian and Czechoslovakian Germans under one flag in order to defeat their common "enemy". Savarkar attempted to consistently equate the German-Jew rhetoric with India's very own Hindu-Muslim debate.

In the same year, he also claimed in one of his speeches that he delivered in Pune that had there been a plebiscite, the Hindus would have opted for a Hindu nation and the Muslims would have chosen to consolidate a Muslim nation. He subsequently featured excerpts of the German Jewish policies in Marathi newspapers. Völkischer Beobachter in the early 1920 s was an anti-Semitic gossip sheet badly in debt and was acquired by the Nazi Party that Hitler himself had been closely associated with, and had even written an editorial titled "The New Beginning" on $26^{\text {th }}$ February, 1925. G L Leszczyński, representative of the German News Agency who was one of the few people responsible for maintaining contact with the Hindu Mahāsabhā, is also known to have dispatched a copy of 'Mein Kampf' to Savarkar on $19^{\text {th }}$ November, 1938 (Casolari 2000; Shirer 1961).

In 1939, RSS leader M.S. Golwalkar drew extensively from the philosophy of nation as perceived by Johann Kasper Bluntschli, who has been defined as an exponent of German ethnic nationalism by political scientist Christophe Jaffrelot and had written about the same in his book 'We and our Nationhood Defined':

"Bluntsley ${ }^{17}$, the famous German writer on politics, defines Nation thus

- "It is a union of masses of men of different occupations and social states, in a hereditary society of common spirit; feeling and race bound

15 ' VölK in German means 'people'. '-ischer', borrowed from Proto-Germanic '-isch' means 'of the nativity or country of'. 'Beobachter' refers to 'Observer'. 'Völkischer Beobachter' would then loosely translate to 'the observer of the nation of the people'.

16 'Sang gațhan' is a Hindi word meaning 'organisation'. Sang gațhanist is a bilingual portmanteau borne by combining Sangațhan and the suffix '-ist', means an organiser.

17 The correct spelling would be Bluntschli. 
together especially by a language and customs in a common civilization which gives them a sense of unity and distinction from all foreigners, quite apart from the bond of the state" (Golwalkar 1939: 58).

It would be intriguing to note that Bluntschli added the essence of an organicist understanding of nationhood, and in the process, defied the legitimacy of the social contract. He further argued that whereas the English word "people" and the French "peuple" represented civilisation, in the German context, civilisation could be derived from "natio", rooted in "nasci", that was associated with birth and race (Jaffrelot 1996: 53).

It is also clear that Bluntschli draws a definitive distinction between organic solidarity, that is racially associated with a nation - an entity that cannot be equated with the mere "sum of people", something that he referred to as an artificial, mechanical form of solidarity that did not match the intensity, fervour and emotional association an individual might have had with the former. Intriguingly, in Mein Kampf, 'Rasse' (Race) and 'Völk' become interchangeable terms and merge to give rise to the concept of 'Organismus' (Ibidem: 59). The subsequent otherisation of those not belonging to this organismic hierarchy, i.e. the Semites, ultimately resulted in one of the most brutal episodes of mass genocide in human history - the Holocaust.

Golwalkar's organicist ideas were representative of his scientific education, and given that his closest mentor Hedgewar was a doctor, the "naturalist" logic of organicism within the realm of social cohesion and cohesive resistance might have been an incentive behind the strong representation of natural science students within the RSS that persists to this day. Although in the context of the neo-Hinduised version of fascism ${ }^{18}$, "society" was bigger than "race", and it emphasised on an ascetic model within its youth organisations where segregation of śakhas ${ }^{19}$ and

\footnotetext{
${ }^{18}$ Fascist and/or quasi-fascist tendencies have been identified within the Sangh Parivar network by Marzia Casolari, Peggy Froerer, Tanika Sarkar and Nandini Sundar among other scholars.

19 'Śakha' is a Hindi word of Sanskrit origin meaning 'branch' or 'tributary'.
} 
samitis $^{20}$, celibacy of sarsangcalaks ${ }^{21}$ and pracaraks ${ }^{22}$ were glorified instead of the idealisation of an aggressive hyper-masculinity as was the case within Nazi youth fronts (Ibidem: 61, 63), the idealisation of an upper caste, hyper-masculine identity within male members of Hindu families across the cow belt where RSS and the Sangh Parivar have enjoyed maximum popularity raises further questions about internalisation of hatred within religious organisations that embody the discipline of military cohorts.

As Jaffrelot derives from his interpretation based mainly on the RSS organisation in Shivpuri, a town some $120 \mathrm{~km}$ far from Gwalior, everything within the organisation, particularly situated in the rural belts is solely based on men. However, the theoretical emphasis laid on the fact that the RSS organisation "is above men" and in particular that the movement does not rely on the authority of a supreme leader, differentiates it from fascist groups. A missing link between a sect, and arguably a fascist organisation, the existential framework of the RSS does not directly coincide with either of the German Nazi organisations or the ones that operated in Mussolini's Italy (Ibidem: 63-64).

While gendered, fundamentalist authorities within the realm of the far right have been known to conform to certain measures that vehemently support the claim that "all others" should be living as second class citizens, a similar propensity has also been observed within the supporters of such regimes. In a fairly recent socio-psychological experiment used to examine the relationship between the social orientation

\footnotetext{
20 'Samit' is a Hindi word meaning committee or organisation. Samitis, similar in function to the śakhas served as a women's and young girls' wing of the RSS, as noted in the interview of interviewee NV62 EX, former member of such a samiti in the Sindh province of erstwhile Punjab. The interview had been conducted by me on behalf of The 1947 Partition Archive on $18^{\text {th }}$ July, 2020. A Hindu nationalist organisation called Rassțra Sevika Samiti has also been found to operate as a women's wing of the RSS. However, this organisation was not formally accepted as the women's wing of the RSS, as Hedgewar believed that the RSS should have remained an organisation only meant for men (Dixit 2013).

${ }^{21}$ The leader of the RSS is referred to as the one who drives [Calak] the entire [Sar] Sangh. The local leaders are called Sarsangcalak.

22 'Pracarak is a Hindi word meaning 'mediator'.
} 
and right-wing authoritarianism, it was found that criteria such as opposition to reservations for backward communities, anti-miscegenation (inter-caste dating or marriage), support for caste based discrimination, reduced aid to the poor, opposition to government aid to lowercastes and a generalised support for hierarchy enhancing policies, such as reducing aid to the poor or regressive tax policy implementation enjoy higher popularity among Hindu fundamentalists (Cotteril et al. 2014). The hierarchy enhancing policies, once implemented in the context of education has led to increased austerity measures and rapid privatisation of the education sector in India.

The Cleansing of the Curricula

The Saraswati Siśu Mandir and the Akhil Bharatiya Vidya Bharati Sansthan (Vidya Bharati) are RSS schools which have been set up all over the country. The Saraswati Siśu Mandir was established to prepare young minds to aid the larger Hindu supremacist propaganda. These schools are known to adhere to a nuanced gendered framework that is utterly patriarchal and apparently aims to groom the good Hindu woman, whose sole concern lies in protecting her chastity and serving the husband - who happens to be portrayed as the "lord" to his goddesswives. Let us consider the portrayal of the character Sit $\bar{a}^{23}$ in 'Ramayana Ki Kathein', a textbook meant for Class 2 students. The only few

\footnotetext{
23 Sittäis the wife of the Hindu god Ramain the Hindu epic Rãmãyan am. She is perhaps the most important female protagonist of Rāmãyanam, who chooses to bury herself alive after Rama asks her to prove her chastity through a verdict passed in his court. Her portrayal however, is not as passive in the original epic as it is in the textbooks used by the RSS in their schools. These books barely reveal the weight of her personality and the indispensable role she played in the Rāmãyanam.
} 
women who express their desire in this story, such as Kaikeyi, Manthara ${ }^{24}$ or Śürpanakha $\bar{a}^{25}$ are shamed for such monstrosity. Not only is the expression of desire equated with monstrosity, but the very portrayal of the good women characters is rooted in a frail, fragile, submissive, passive woman figure whose pictures are drawn in pale colours to express her ill fate and annoying helplessness (See: Chauhan 2010).

On the other hand, Adarsh Vidya Mandir in Maharashtra serves as a boys only school for the elite section of the RSS (Mathur 2008). Established in 1977, the Vidya Bharati network in India runs more than 18,000 schools, employs over 150,00o teachers and educates some 3.5 million students worldwide (Vidya Bharati Selected as Vanguard Member by the International Development Innovation Alliance IDIA for its Million Lives Club 2020; Lal 2006)). The Sanskriti Dnyana textbook used in these schools circumnavigates the differences between Vedic civilisation and the Indus Valley civilization by stating that it was simply Bharatiya $^{26}$ civilisation. Further, laying emphasis on the notion that Pakistan is where Indus valley civilisation once was, it is claimed an enemy state unworthy of existence, inhabited by Muslim "foreigners" who once invaded the holy Hindu land of India.

Vidya Bharati schools were set up particularly in urban slum regions and in tribal belts and in contrast, in urban pockets for the English speaking RSS elite whose motives lie in migrating to a first world country (Bakaya 2004; Mathur 2008) initially in order to prevent proselytisation, the entire discourse of which according to RSS literature, has perpetually happened on sword point (Sarkar 2005; Manjrekar 2011).

\footnotetext{
24 Kaikeyiwas king Dashrath's second wife and the most significant of his three queens. She was initially kind to her step son Ram, who was the son of queen Kaushalya. However, under the influence of her "crooked" maid Manthara, she chose to send Ram to the forest for fourteen years.

${ }_{25}$ Súrpanakhā was Ravana's sister, who upon meeting the young Rama at the forest of Panchavati was smitten with him. However, Rama claimed he was faithful to his wife Sitza and was uninterested in taking a second wife.

${ }^{26}$ Bharatiya, derived from 'Bharat', is a Hindi word meaning 'Indian'.
} 
Teachers hired in these schools are connected with the Sangh network either through the connections established by fellow family members or with a background that assimilates with the framework of Hindu nationalist propaganda (Bakaya 2004; Sarkar 2005; Manjrekar 2011).

School pedagogy is carried forward beyond the school into the familial space and frequent parent teacher meetings are organised to ensure the same. The children are unaware of Sikh or Christian festivals and holidays. Furthermore, they learn to dissociate the role of BJP leader in inciting communal violence and the erstwhile chief minister of Gujarat during the 2002 riots - Narendra Modi ${ }^{27}$. Most students tend to vilify any entity associated with Islam and identify with Pakistan as an autocratic state in contrast to India, which encourages diversity and cultural inclusivity (See: Rajeshwari 2007).

The RSS claims that the modern mainstream education system was influenced by Macaulay and other colonial masters and continues to be affected by colonial hangover. RSS officials have previously claimed that NCERT ${ }^{28}$ books are false and pseudo-secular. The Vidya Bharati schools seem to blend Hindu political symbols and militancy with sacredness. Struggles between the 'divine' and the 'unholy', demons and the divine figures, colonials and nationalists, Hindus and Muslims are portrayed in such a way that it becomes evident that they share an undifferentiated continuum. Hindu heroes are almost always upper caste men (See: Sarkar 2005).

\footnotetext{
${ }^{27}$ Narendra Modi is a BJP leader who is serving his second term as the Prime Minister of India. He had won the national election in 2014 and assumed office again in 2019. He has been subject to critique by academics, scholars, activists, politicians for the kind of policies that he advocates are largely against the sentiments of minority communities. The far right regime in India that is currently in power has been reflective of symptoms of fascism (Ramanathan 2020).

${ }^{28}$ The Central Board of Secondary Education (CBSE) is a national level educational board managed by the central government of India. Schools affiliated to this board recommends the use of books and curricula solely designed by NCERT (National Council of Educational and Research Training), an autonomous organisation run by the government of India. Schools that are affiliated with the CBSE board are formally incorporated in the list of approved schools following the prescribed and/or approved courses as well as preparing students for the board's secondary and/or senior secondary examinations.
} 
Further, Gauravśāli Bhārat (Proud India), the social science textbook used in Class 5 and 6 in these schools does not mention the positive achievements of any of India's "foreign" ruler. Further, the Varna system has been mentioned without taking into consideration the hierarchy element that it operates on. These textbooks avoid the question of women's position in society and the question of untouchability altogether. It also twists historical facts and has been known to draw historical non-facts and juxtapose them with the authentic portions to create a believable blend of Hinduised knowledge for children (See: Iwanek 2015).

The broad RSS influence on education goes much beyond the range of schools directly controlled by it. A Śiśu Mandir and an adjacent DAV school operated by the Arya Samaj in Delhi had been found to be similar in appearance and cognitive tone. The usual colourful pictures, decorations expected to be found in nursery schools were absent: birds, animals or flowers had been replaced by portraits of the standard Hindunationalist pantheon. In RSS schools, Hindi seems to lack a genre of secular children's literature, which contributed to the spectacular success of the Amar Chitra Katha series (Basu et al. 1993: 46). Gendered discrimination forms a large part of socialisation, interaction and the institutionalised curricula in these schools (See: Ambikar 2008).

The Vidya Bharati schools that operate in Gujarat engage in direct attempts to desecularise the state by implementing a system that embodies the Hindu nationalist propaganda so profoundly within itself that the two entities become inseparable. Work done in this area reveals that the syllabus prescribed by State government schools in Gujarat, outline a History of India where the modern nation is seen as synonymous with "Hindu". The Indian culture which is seen as Hindu Culture, is projected as superior to any other culture. The caste system is not seen as a social stigma but a gift of Varna system where the division of labour had been a necessity to Hindu religious philosophy. Adolescent 
students are taught about the 'negative aspects' of Gandhi's non-cooperation movement, and a social studies textbook has chapters on 'Hitler, the Supremo' and 'Internal Achievements of Nazism'.

The textbooks also shows through examples how Christian priests acquire wealth by non-payment of taxes while there is complete silence about the problems pertaining to Hindu Brahmin priests (Rajeshwari 2007). "Historical truths" such as the notion that Iran was settled by Aryans from India, that Homer had adapted the Iliad from the 'Rāmāyaṇam' or Jesus Christ wandered about the Himalayas and was inspired by Hinduism, Alexander suffered a humiliating defeat at the hands of Porus, the Qutab Minar was constructed by Samudragupta and was previously known as Vishnu Sthambha are embodied within the curricula of RSS schools (Lal 2009).

The former general secretary of the Vidya Bharati, Dinanath Batra is said to have been consulted when the BJP-led NDA coalition tried changing the contents of NCERT social science textbooks in 1999-2004. Batra is now the leader of Sikșā Bacāo Āndolan (Save Education Movement), which is perhaps an RSS affiliate and has its office in a Vidya Bharati school. He compelled Penguin Books India to withdraw Wendy Doniger's book 'The Hindus: An Alternative History'. He led a protest against the inclusion of Ramanujan's essay on Rāmāyanam in the Delhi University curriculum and started a litigation process which ended with the government's DOIng away with the English language component of the Civil Services Aptitude Test (Iwanek 2015).

Sex-role differentiation is visible in children's textbooks that are used to teach nursery students have illustrations of devoted Hindu women praying in front of a holy Tulsi plant, the image of a man to depict 'Gyani' (the knowledgeable) whereas there is no image of a knowledgeable woman or vidushi. The Varnamala also incorporates the picture of a moustached man with a Tilak (depictive of upper caste status) riding a horse to introduced the word 'Sawar' with the letter 'Sa'. 
The textbooks are known to exhibit male children playing with toy horses and toy weapons whereas girls are shown to be playing with dolls or soft toys. Qualities such as courage, wisdom, assertiveness, competitiveness and leadership are set to be the ideals for male children whereas women are shown to tend to household chores, domestic work and are seen in roles where they are passive, not assertive (See: Chauhan 2013).

Balika Śikșān ${ }^{29}$ (BS), a series of books that were published by Vidya Bharati in order to mark the $5^{\text {th }}$ anniversary of the first RSS schools set up in India outlined the numerous good deeds that the good Hindu girl, while transcending into womanhood, should be incorporating within herself. The pressing need to discipline the mind and body of the girl to resist the attractions of a media and market-driven globalised modernity that could signal the downfall of tradition is given a lot of importance in these publications, which were intended to be used as textbooks, supplementary material in schools and resource material for teacher training. The pedagogic aim of BS is to build on recognition and familiarity with a particular set of symbols, rituals, customs and sacred geographies to construct subjectivities and dispositions in Hindu girls that are suited to the ideal of an ennobled Hindu womanhood. Thus, the purpose of acquiring knowledge for the Hindu girl is solely associated with her "naturalised domesticity" (Manjrekar 2011).

Corporal punishment is often accompanied by admonishment in front of the class if students disobey rules. A very strong emphasis is laid on "disciplining" the child in RSS schools (Froerer 2007a). Other RSS offshoots associated with pedagogical training include Ekal Vidyalaya Foundation that runs single teacher schools in poor and tribal areas, Vanvasi Kalyan Ashram, the original aim of which was to establish schools, ashrams and boarding facilities for tribal children particularly in the Central and Central Eastern tribal belts of India (Froerer 2007b)

29 'Balika' in Hindi means girl. 'Shiksha' means education. 'Balika Śikșān' literally translates to "education of girls". 
and Vivekananda Kendra, which is focused on the Northeast of India, and, to a lesser extent in the southern part of India (Iwanek 2015).

Many of the Vidya Bharati schools are affiliated to the local State Board ${ }^{30}$, while few are affiliated to the Central Board of Secondary Education (CBSE) and their intervention occurs by adding to the prescribed curriculum new areas - Naitik Sikșā (moral education) being an area that is strongly emphasised upon in these schools. A special, compulsory Vidya Bharati curriculum with six extra subjects, is superimposed upon the official syllabus, though, due to political protests in Parliament and State assemblies, not (yet) recognised or evaluated by the official certification system: (i) Moral and Spiritual Education; (ii) Culture and History; (iii) Sanskrit; (iv) Physical education; (v) Yoga; and (vi) Music and Art (Bakaya 2004).

Vidya Bharati schools theoretically emphasise on Sāririk Sikșā (physical education), but it is doubtful if they have a separate physical education curricula that is any different from physical education or sports curricula in other schools in India. A look at Vidya Bharati books makes the anti-intellectual spirit even more apparent. The Vidya Bharati educationists seem to interpret Yoga ${ }^{31}$ entirely in terms of acrobatics. Their Yoga manual is the Bhagwat Gita itself - a religious and devotional text, not a rigorous, technical exposition of Samkhya or Yoga. The Gita offers the Kshatriya a reconciliation of moksha, ultimate liberation from rebirths, with worldly concerns and bloody violence (Bakaya 2004).

Nursery students enrolled in such schools are trained to valorise the Hindu nationalist values by listening to nationalist songs and stories

\footnotetext{
${ }^{30}$ The state education boards in India are education boards run by the separate state governments operative within the federal system of the country or government administered autonomous educational bodies operative particularly locally.

${ }^{31}$ The Sanskrit term Yoga meaning 'harnessing' all forces to a single end could mean many different things. As codified by the sage Patanjali in the 'Yoga Sutra', more compatible with a 'comfortably seated' individual (no acrobatics) than with rows of children repeating 'Om' in unison - using an experimental meditational technique, seeking an ecstatic state of consciousness, freed of all objects of consciousness (Bakaya 2004).
} 
(Froerer 2007b). Teaching the Sanskrit language to students is considered very important - particularly shlokas and prayers are recited in Sanskrit classes. Supplementary textbooks, like Itihās Ga Raha Hai ${ }^{2}$ and Bodh Mala were used to impart Hindu morals straight into the student's heart and are considered superior to ordinary secular schools by the parents of most students enrolled in these schools (Ambikar 2012).

"Vedic Mathematics" alleged to be indicative of the mathematical prowess of the Vedic peoples but which contemporary Indian scientists describe as nothing more than a computational tool with no Vedic origins, is introduced in the third standard. What is disheartening is that the social science textbooks in India, irrespective of whether the farright has been in power or not, have idolised Hindutva. That the average Hindu man has been from the ancient times, a saintly being who introspected the intricacies of a metaphysical understanding of his surroundings is an imagined narrative that has reified such a concept. On the contrary, the annexation of land under monarchs and the method of warfare discussed particularly in the Mahābhärata does not prove that non-violence was practiced and/or embodied with the Hinduness of one's being (Mathur 2008).

An examination called the 'Sanskriti Gyān Parīkșà', is conducted in Vidya Bharati that tests the level of one's knowledge of his culture conducted at an all-India level. The "supplementary" subjects and textbooks add up to a more thoroughgoing intervention than possible through an official scripture lesson weekly (Sundar 2004, 2005). The Sanskriti Gyān Parīkșā Praśnottari33, which students in RSS schools are invited to take in exchange of a certificate includes four questions and answers (Sundar 2005) ${ }^{34}$ :

\footnotetext{
32 Itihās Ga Raha Hai is no longer in active use as a textbook.

33 Sanskriti Gyān Parīșā Praśnottari translates to 'Cultural Knowledge Exam', which is a test that is taken by students who study at Vidya Bharatischools. While in some schools, this exam might have been mandatory, in others they are considered voluntary.

34 This question and answer section was used previously as a part of Sanskriti Gyān Parīkșā Praśnottari and is not in active use anymore.
} 
“Q: Which Mughal invader destroyed the Ram temple in 1582?

A: Babur

Q: From 1582 till 1992, how many devotees of Ram sacrificed their lives to liberate the temple?

A: 350,000.

Q: When did the program of collecting bricks for the Ram Mandir begin?

A: September 30, 1989.

Q: When did the Karsevaks fly the saffron flag on Ramjanmabhoomi?

A: October 30, 1990”.

Incidentally, the RSS demolished the Babri Masjid, which was a sixteenth century mosque built in Ayodhya, claiming that it had previously been the birthplace of Hindu god Ram, before the mosque had been forcibly built by demolishing the Ram Mandir. The few Vidya Bharati schools as well as the other schools affiliated with the CBSE follow The National Council of Educational Research and Training (NCERT) books, and it is here that the Hindu far right's pedagogical curricula initiates itself in a far more covert manner which is neither pronounced nor vulgar, as in the aforementioned Q\&A section. Following the appointment of Murli Manohar Joshi as the Minister of Human Resource Development, J.S. Rajput, considered a Joshi favourite, was appointed as the director of the NCERT in July 1999. This was precisely when RSS' agenda to Hinduise pedagogical curricula with the newfound motto to "Indianize, Nationalize and Spiritualize" (Sundar: 2004, 2005).

A bench at the Supreme Court of India subsequently in 2002 suggested that the comparative analysis of religions was "premature and hypothetical", and even exclusionary (See: Deshpande 2002). These textbooks that had been morphed in between the period of 1999-2004 had subsequently been withdrawn and new textbooks under the United Progressive Alliance (UPA) 35 government had been adopted in 2004-

35 The United Progressive Alliance (UPA) government is the official opposition to the BJP-led National Democratic Alliance (NDA). The conglomerate is constituted out of centre-left and liberal parties, and the largest party that is a part of the UPA is the Indian National Congress (INC). 
2009. In context of government schools, a literary scheme called The Infosys library programme distributes biographies of "great Indians" (mainly published by the Rashtrothana Publication linked to RSS) where mythical figures outnumber social reformers and RSS leaders replace Gandhi and Nehru (Committee of the Central Advisory Board of Education 2005).

Other organisations who are a part of the Sangh Parivar such as the Seva Bharati, Sanatan Sanstha and Hindu Janajagruti Samiti (HJS) are known to dissipate their Hindu nationalist propaganda through educational media. Founded in 1979, and keeping up with the approach adopted by the RSS, Seva Bharati (Service of India) emphasises on inculcating their ideological values within lower caste children in slum areas near Delhi. The foremost official objective of the Seva Bharati is to eradicate untouchability. In the early 1990s, Seva Bharati had managed to open fifteen Sanskrit Kendras ${ }^{36}$ and 129 Bal and Balika Samskar Kendras $^{37}$ attended by 19,304 students, supervised by 352 teachers, many of whom were RSS workers themselves. It set up tutorial centres that offered vocational training to students belonging to economically downtrodden backgrounds, electricity and electronics apprenticeship courses for school dropouts as well as dress-making centres for girls with the goal of making their families self-sufficient (Jaffrelot 2008a).

The Sanatan Sanstha ${ }^{38}$, on the other hand, is a Hindu nationalist group based in Goa, founded by hypnotherapist Jayant Balaji Athavale in 1999. People who shared links with this organisation have been arrested on charges of murder of author Narendra Dabholkar (Yadav

36 'Kendra' is a Hindi word meaning 'center'. Sanskrit Kendras refers to Sanskrit learning centers.

37 ' $\mathrm{Bal}$ and ' $\mathrm{Balika}$ ' in Hindi refer to 'boy' and 'girl' respectively. 'Samskar' is a Hindi word of varied Sanskrit meaning that in the this context refers to "forming of mind", "education", "training" and perhaps ceremonial practice (Monier-Williams 1899) 'Bal and Balika Samskar Kendra' refers to the Sam skära learning centres for boys and girls.

38 'Sanatan' is a Hindi word meaning 'perpetual'. The phrase 'Sanatan Dharma' is used to refer to 'eternal order', and in general, is used to refer to the Hindu religion. 'Sanstha' in Hindi means Organisation. Sanatan Sanstha loosely translates to 'eternal organisation'. 
2016), communist leader Govind Pansare (Pansare murder Chargesheet: "Teen saw Sanatan member on crime spot" 2015), Kannada scholar M.M Kalburgi and journalist Gauri Lankesh (Forensic Analysis Finds Same Gun Used to Kill Gauri Lankesh and M.M. Kalburgi 2017) although such charges were later ruled out by the Central Home Ministry (Sen 2015), while the BJP-led NDA coalition had been enjoying national power.

Previously, in 2008, members owing allegiance to the organisation had been held responsible for planting bombs in auditoriums in Mumbai (Theatre blast convicts get 10 years in jail 2011). In February, 2020, the Sanstha held an exhibition at the Amrita Vishwa Vidyapeetham, founded by the "hugging saint" (Delaney 2019) Mata Amritanandamayi, who was awarded the Hindu Renaissance Award from Hinduism Today and Vishwaretna Puraskar (Gem of the World Award), bestowed by the Hindu Parliament in 2013, as ruled out by the Vidyapeetham website (Awards and Honours received by Chancellor Amma, n.d.) for her philanthropic and charitable service to the people. The Sanstha further attempted targeting government schools by organising workshops for school teachers that promoted "good behaviour" (Singh 2015). The Sanatan Sanstha is directly associated with a platform called Hindu Janajagruti Samiti (HJS) (S. Debnath, personal communication, Sep 23, 2020)39, that has been claimed to be an offshoot of the RSS (Jaffrelot 2008b). Both the Sanstha and HJS conduct similar meetings or webinars discussing the inevitability of the Hindu Rashtra in terms of astrology and faith.

Geopolitically, the Hindi belt region has been a stronghold to the Sangh Parivar. Benares, being a pilgrimage site, has been used by the Hindu nationalists to promote educational media that incites a majoritarian, Hindu supremacist purview of Hindusthan. Canada-based Indian filmmaker Deepa Mehta had been making her film 'Water', a part of the popular Elements trilogy in January, 2000. The film wanted to

39 Member of the Hindu Janajagruti Samiti (HJS) West Bengal Chapter. Personal communication. 
explore the kind of drudgery faced by Indian women in the 1930s, with one of the widows being pushed off to take up prostitution in order to earn a living. Mehta subsequently received death threats for allegedly having insulted Hindu culture in a place of Hindu pilgrimage. The people leading protests against her included members of the BJP, the Kaśi Sanskriti Rakșā Sangharș Samiti (KSRSS)40, a member of the Sangh Parivar and other organisations that constituted the Parivar ${ }^{41}$, despite the film having obtained clearance from the central authorities, in a period when the NDA coalition had been in power (Casolari 2002: 1413).

Historically, Benares has been associated with movements that under the façade of the city being a holy site has led to propagation of educational media that was based on Hindu fundamentalism. One example would include the Benares Hindu University (BHU). Madan Mohan Malaviya, the founder of the Akhil Bharatiya Hindu Mahāsabhā, was responsible for having founded BHU. As a member of 'Prayag Hindu Samaj, he set to lay the foundation for a Hindu university as a part of the larger project to promote Hindi as a national language. The faculty that was chosen at the Hindu University of Benares were to belong from Hindu aristocratic families. The Hindu University of Benares received government sanction in 1915 as Benares Hindu University (BHU). Malaviya himself served as the chancellor of the university from 1919 to 1939, and the initial scheme of the university remained to provide traditional subjects more emphasis over Westernised disciplines. Although English was adopted as the official language after disputes with the authority, Sanskrit, Hindi, religious studies and philosophy remained important disciplines. Apart from the construction of the curricula, the university acted as a think tank for political Hinduism, beyond the local level (Ibidem: 1417).

\footnotetext{
40 'Kaśi' is another name for the city of Banaras. 'Sanskriti' means 'culture', 'Rakș $\vec{a}$ means 'to protect', 'Sang gharș' means 'fight' or 'struggle' and 'Samiti' means 'organisation'. 'Kaśi Sanskriti Rakșā Sang gharș Samit' would loosely translate to 'Kaśi Cultural Preservation and Protection Organisation'.

${ }^{41}$ Has been used to refer to the Sangh Parivar itself, an explanation to which has been provided at the beginning of the article.
} 
It was however, only during the reign of one the most important leaders of the RSS, M.S. Golwalkar that the RSS had extended into a pan-Hindu nationalist organisation, while its "shakhas" in the foreign countries gained potential. These organisations included Bharatiya Swayamsevak Sangh or the Hindu Swayamsevak Sangh (HSS) (Goyal 1979).

Purnima Bose claims that both the Hindu American Foundation (HAF) and Hindu Education Foundation (HEF), both of which are Hindu advocacy groups located in the United States are off-springs of the HSS. She further claims that organisations associated with the HSS have now been established in England, Trinidad, Hong Kong and the Netherlands besides the US. While the HSS (US) is registered as a 501(c) (3) non-profit cultural organisation and public charity, its website features a link to the RSS and describes its mission as "ideologically inspired by the RSS vision of a progressive and dynamic Hindu society that can deal with its internal and external challenges, and contribute to the welfare of the whole world". On its website, we find the HEF is "an educational project of Hindu Swayamsevak Sangh" that "strives to replace...various misconceptions with a correct representation of India and Hinduism" (Bose 2008: 19).

During the certification of sixth grade history and social science textbooks in 2005, two organisations that closely operate with the RSS as their international allies - namely, the Hindu Education Foundation (HEF) and Vedic Foundation (VF) complained about the discrimination against Hindu culture in textbooks that had been published by the California State Board of Education (CBE). While most scholars in disciplines associated with South Asian studies agreed that there were certain blunt errors that had been printed in these books, such as in one of the textbooks, Hindi had been described as a language with eighteen alphabets written in the Arabic script (Ibidem: 15). 
The HEF and VF, however, sought to interject content within these textbooks that diluted and in some cases, exempted and/or simply defied history to have made Hindutva (Hinduness) more palatable to American sensibilities. Since Golwalkar emphasised about the absurd claim that speakers of Indo-European languages or "Aryans", as having been indigenous to India in his book 'We, or Our Nationhood Defined (1939)' instead of having migrated from elsewhere, the Sangh Parivar has sought to nurture this narrative as the truth. In the "Vision and Mission' section provided in the official website of the RSS, the following words have been mentioned"

"Looking to the West as the pinnacle of civilization, irrationally perpetuating the Britishers' self-serving theories of the 'White Man's burden'; that the Hindus were 'a nation-in-the-making', that the Hindus had achieved nothing of significance in the past, that Westernisation was the only hope for 'the dying race' that were the Hindus; unquestioning acceptance of myths floated by Westerners even in the name of history (e.g., that the Aryans came from outside), that life in Bharat was and had always been at a near primitive state; - acceptance of such numerous myths had virtually become mandatory for anyone with the slightest pretensions to education or intellectuality" (Antidote to Self-Oblivion 2012).

In his book 'We or Our Nationhood', Golwalkar had written:

"From internal evidence also it can be shown that whereas the Ramayan is referred to in the Mahabharat, no mention of even the dynasties of Bharat and others of the latter epic is traceable in Valmiki's work. The language of the two works also gives ample proofs of Mahabharat being a much later work. But obsessed with the idea, that Aryans came to Hindusthan ${ }^{42}$ from somewhere near the Caspian Sea or the Arctic region or some such place, and invaded this land in bands of marauder?...Unfortunately such misconceptions are stuffed into the brains of our young

42 'Hindusthan' - a deliberate modification of the Persian 'Hindustan' - was used earlier by Savarkar in the early 1920 (Bakaya 2004). 
ones through text books appointed by various Universities in the country. It is high time that we studied, understood and wrote our history ourselves and discarded such designed or undesigned distortions" (Golwalkar 1939: 40).

The HEF and VF further pressured on the idea of defining the caste problem as one concerned technically with only division of labour, and demanded that the word 'Dalit' be excised from the textbooks. They argued that the parts that had been associated with women's oppression should also be exempted (Bose 2008: 16). The HEF's understanding of Hindutva, that lay claims of Hindus having invented nuclear power, supersonic aeroplanes, flying UFOs and having made it to the moon seems to be an intersection of absurdity to the point that it is frightening coupled with comic relief (Ibidem: 20).

In India

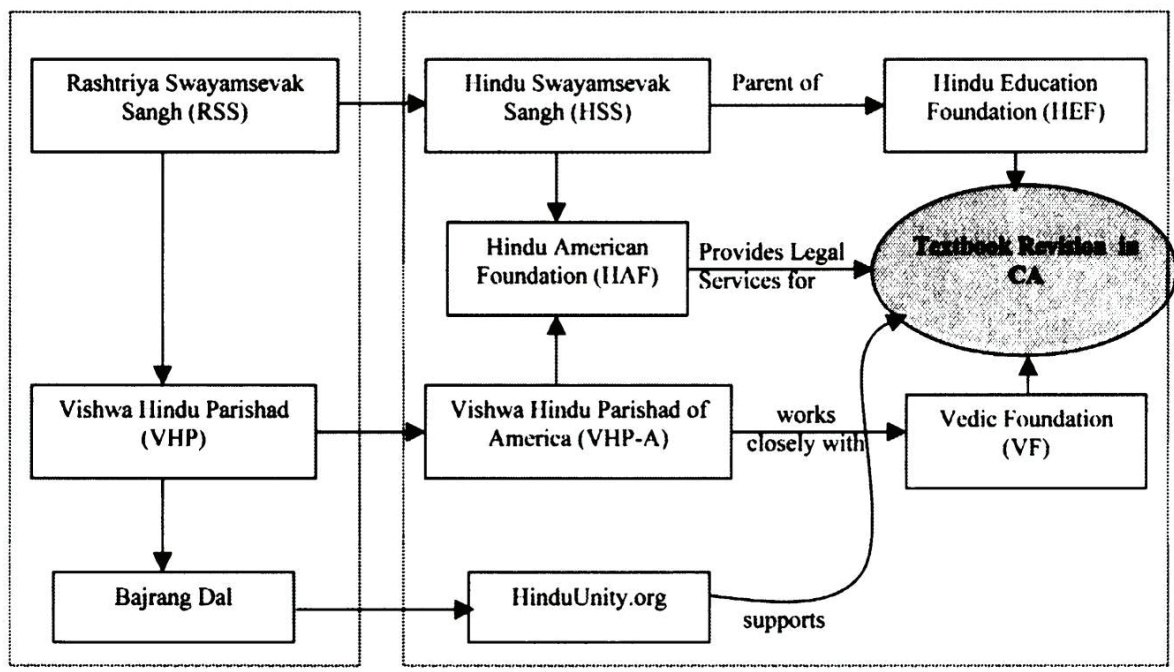

Note. This chart depicts the hierarchical and/or parallel operation of the sub-organisations that constitute the Sangh Parivar in India and the United States. Retrieved from Bose 2008: 19.

Changes in textbook content however has never been as blunt as it was in July 2020, when the board scrapped off a lot of important topics from 
all social science textbooks while allegedly trying to reduce the burden of the syllabus on the students. When the BJP first came to power in 1998, Sangh sympathisers were placed on the NCERT, the school curriculum development and review body at the national level (Visweswaran et al. 2009). However, the situation changed when the UPA coalition won the national election and consistent attempts were made to push back important changes in textbooks as well as exempt Hinduised notions of education within the period of 2004-2014. These books consisted of important details on caste politics, colonial history and democracy.

Although the board this year claimed that these changes were being made in order to reduce the burden of a huge syllabus by omitting thirty percent of the content that it included within curricula until then (Nandini 2020), the pattern of exemption is depictive of something far more appalling than that.

A chapter that consists of the history and chronological evolution of the print media, women's role in media and censorship in the modern world titled 'Print Culture and the Modern World' (NCERT 2013c: 153175) has been removed from 'India and the Contemporary World-2'. The unit titled 'Early Societies' (NCERT 2007: 1-48), which is about the advent of the earliest civilisations of the world, a chapter titled 'Nomadic Empires' (NCERT 2007: 104-122), that highlights important details about how the Mongols under the rule of Genghis Khan created an early military machine. It also throws light on the fact that the Mongol Khans themselves belonged to a variety of different faiths including Shaman, Buddhist, Christian and a few of them even conformed to Islam. They seldom allowed their religious identities to interfere with public policy design. The Mongol rulers recruited administrators and armed contingents from varying religious and ethnic backgrounds and their regime had been "multi-ethnic, multilingual and multi-religious that did not feel threatened by pluralistic constitution".

The chapter 'Confrontation of Cultures' (NCERT 2007: 168-184) examines different opinions about Spanish and Portuguese conquests in 
the Americas, the "discovery" of the Indian people, colonialism and slave trade. These chapters have been erased from 'Themes in World History-I', which is the textbook for Class 11 students.

A chapter titled 'Through the Eyes of the Traveller' (NCERT 2011: 115-139), that is of utmost significance given that it highlights how Iranian scholar Al-Biruni, who was a polyglot well-versed in Syriac, Arabic, Persian, Hebrew and Sanskrit developed an interest in India and Sanskrit works on astronomy, mathematics and medicine when he relocated to Ghazni as a hostage after Sultan Mahmood invaded Khwarizm. He spent years learning Sanskrit himself and studying religious and philosophical texts before having written the bewildering 'Kitab-ulHind'. Al-Biruni criticised tenets of rigid Sanskrit texts, and despite having somewhat accepted the Brahminical interpretation of the caste system, refused to accept the notion of "social pollution", which according to him was contrary to the laws of nature. Even more importantly, details about women slaves, $\mathrm{Satī}^{43}$ and women labourers have been omitted. It would be important to note that $S a t^{-}$was a practice validated by orthodox Hindu fundamentalists and was a symbol of religious devoutness that compelled women to burn themselves alive after their husbands' death by sacrificing themselves to the burning pyre.

The chapter titled 'Understanding Partition' (Ibidem: 376-404) that highlights several important details about the partition of India and Pakistan in 1947, has been fully exempted. This chapter compares the gravity of the Partition in 1947 with the history of the Nazi holocaust (Ibidem: 381) and speculates the causalities that ultimately led to partition. The chapter further highlights the reason behind the transcendence of what was supposedly a communal problem into a phenomena

\footnotetext{
43 'Sat' is a Sanskrit word meaning "good wife". 'Sat' was perhaps used to refer to the good wife who took part in the ritual referred to as 'sahamarana' (dying together), 'sahagamana' (going together), 'anugamana' (going after) or 'anumarana' (dying after) and at a later date the more literary euphemism 'Satīdāha' (burning of the Sati) in which the widow of a dead man immolated herself (and was compelled to, more often than not) in the burning pyre of her dead husband (Weinberger-Thomas 1999).
} 
so big that it divided a country into two separate parts. It then emphasises on the role the British colonisers had played behind the partition and discusses the ill fate of the victims of the violence, riots and compelled migration that followed.

Interestingly, the chapter also highlighted details about the cow protection movement that angered the Muslims in the 1920 s and 1930 s and was one of the many contributive factors that ultimately resulted in the Partition. The divinity of the cow has recently been reinstated, with the saffron regime trying its best to insinuate conflict amongst the beef eating Muslim community as well as the mostly upper-caste Hindu Brahmins. It is peculiar to juxtapose this reality with the fact that the practice of cow sacrifice and eating beef prevailed among the Indo-Aryans.

There is ample evidence of beef eating in early India in multiple Dharmaśāstras (Jha 2001). D.N. Jha, the historian who published a book titled 'The Myth of the Holy Cow' received death threats for raising questions about the venerability of cows (Puniyani 2003). The efforts taken by the Arya Samaj44, an apparently non-violent Hindu organisation that pressed on the needs to proselytise the Hindus who had converted to Islam, often referred to as 'Śuddhikaran' (purification), was another incident that agitated the Muslim communities at that time.

The already brief but somewhat engaging account of the democratic constitution of South Africa has been removed from the chapter 'Constitutional Design' (NCERT 2015: 41-42), which began with a brief outline of Nelson Mandela's contribution to the anti-apartheid movement.

A chapter titled 'Democratic Rights' (Ibidem: 96-110), that begins with an introduction aimed towards the understanding of the events at

44 The Arya Samaj, founded in 1875 by Dayanand Saraswati, a Brahmin hailing from Kathiawar, Gujarat, was a Hindu reformist organisation that denounced murtipujä (idol or image worshipping) and instead, emphasised on the presence of the almighty in one's devotion to his work, or alternatively an omnipresent entity that did not need to be addressed through idols. Arya Samaj gained widespread popularity in the $19^{\text {th }}$ and $20^{\text {th }}$ century, particularly because of its attempts to prevent proselytisation and re-convert those who had been proselytisation into Islam or Christianity - a process which was referred to as 'suddhi or 'śuddhikaran', a Sanskrit word meaning 'purification' (See: Hardiman 2007). 
the Guantanamo bay that later also makes students aware about the Kosovo massacre in Yugoslavia, citizen's rights in Saudi Arabia, the activities undertaken by the Amnesty International and a basic concept of a democratic constitution, fundamental rights including right to choose one's own religion and how they are important to building a democratic nation has been completely removed.

The removed chapter 'Democracy and Diversity' (NCERT 2013c: 2937), begins with the story of African-American athletes Tommie Smith and John Carlos at the 1968 Olympics and then transcends to the broader concepts of the differences between 'political' and 'apolitical' and the importance of representation, Dalit identity politics, cross-cultural harmony, international cooperation and peace. The scrapped chapter 'Gender, Religion and Caste' (Ibidem: 39-54) had an intriguing way of putting together stereotyped perceptions of women in the Indian society, objectification of womanhood, women's political representation, religious diversity, fundamentalism, communalism and the atrocious nature of caste-based discrimination within Indian communities.

A chapter titled 'Popular Struggles and Movements' (Ibidem: 57-68) that had highlighted the Cochabamba Water War, because of which Bolivia was under immense pressure since the World Bank consistently compelled the city of Cochabamba to allow the construction of a dam irrespective of the public costs it would garner and the impacts it would have on the environment to Aguas Del Tunari, a joint venture inclusive of the American multi-national corporation Bechtel. The series of protests finally led to the victory of the spontaneous social movement that had evolved locally. The chapter then merges together the greater narrative of the importance of social movements in the evolution of democracy and briefly mentions the Indonesian Peasant Movement, the organisational consolidation of backward and minority communities as well as several movements to save the environment including the 'Narmādā Bacāo Āndolan (Save river Narmada Protests)'. 
The removed chapter titled 'Challenges to Democracy' (Ibidem: 101112), introduced students to the idea of international understanding of conflicts and provided historical instances from countries including Chile, Poland, Ghana, Myanmar, Mexico, China, Pakistan, Iraq, South Africa, Saudi Arabia, Yugoslavia, Belgium, Sri Lanka, Northern Ireland, Nepal and Bolivia. It also highlighted the role of the United States as a functioning superpower at the United Nations, the problem of racial discrimination in the US and put a gentle reminder about the infamous prisons at the Guantanamo Bay.

A chapter titled 'Federalism' (NCERT 2006: 150-175) and the sections 'Why Local Governments?' (Ibidem: 177-179) and 'Growth of Local Government in India' (Ibidem: 179-181) from the chapter 'Local Governments' have been removed. Entire chapters describing the accounts of 'Citizenship' (NCERT 2014b: 79-96), 'Nationalism' (Ibidem: 97-110) and 'Secularism' (Ibidem: 111-128), which included details about Dalit seclusion and vote bank politics in India have been removed from 'Political Theory'.

Although the chapter titled 'Nationalism' was inclusive of brief sections on pluralism and Rabindranath Tagore's critique of nationalism, it somewhat abruptly ends the discussion about nationalism in Germany and Italy by only suggesting how nationalism helped in unifying and consolidating these states in the nineteenth century. It does not provide any details about the later malignancy of nationalistic ideologies and their metamorphosis towards totalitarianism and/or fascism.

Chapters titled 'Rise of Popular Movements' (NCERT 2007: 128-147) and 'Regional Aspirations' (Ibidem: 148-171) have been fully exempted, too. At a time when the BJP-led state government is trying to impose the Citizenship Amendment Act (CAA) 45 while simultaneously associat-

45 The Citizenship Amendment Act (2019) was an amendment to The Citizenship Amendment Act (1955), which provided illegal immigrants from neighbouring countries a path to procure citizenship in India. Several critics and a large section of the Indian population perceived the act to be a part of the BJP-led 
ing the procedure of persecution of so-called, largely non-Hindu "immigrants" by issuing a National Register of Citizens (NRC), which has already faced nationwide protests, the removal of chapters on citizenship and secularism are not entirely unprecedented. The CAA has been debated largely within and beyond scholarly circles and remains in opposition with the Article 14 of the Indian Constitution.

The remaining chapters titled 'Power Sharing' (NCERT 2013b: 1-12), 'Political Parties' (Ibidem: 71-88) and 'Outcomes of Democracy' (Ibidem: 89-100), 'Novels, Society and History' (NCERT 2013c: 177200), all meant for Class 10 students, embody the ideas of secularism, inclusivity and progressive values.

Chapters titled 'Paths to Modernisation' (NCERT 2007: 231-257), 'Kinship, Caste and Class' (Ibidem: 53-81), 'Bhakti-Sufi Traditions' (Ibidem: 140-169), 'An Imperial Capital: Vijayanagara' (Ibidem: 170195), 'Kings and Chronicles' Ibidem: 224-256), 'Rebels and the Raj' (Ibidem: 288-315), 'Mahatma Gandhi and the Nationalist Movement' (Ibidem: 346-375) and perhaps most importantly, 'Framing the Constitution' (Ibidem: 405-432), 'Freedom' (NCERT 2014b: 17-30), 'Equality' (Ibidem: 31-52), 'Social Justice' (Ibidem: 53-66), 'Rights' (Ibidem: 6778), and essentially the chapters 'Constitution: Why and How' (NCERT 2006: 1-25), 'Rights in the Indian Constitution' (Ibidem: 26-50), 'Election and Representation' (Ibidem: 51-77) and 'The Philosophy of Constitution' (Ibidem: 220-241) meant for Class 11 and 12 students have not been scrapped yet, and would continue to give adolescents a basic idea about living in harmony, how conflict is perceived democratically and the importance of debate.

NDA coalition's anti-Muslim policies. The Bill further seeks to grant immunity to the migrant of the aforesaid Hindu, Sikh, Buddhist, Jain, Parsi and Christian communities so that any proceedings against them regarding in respect of their status of migration or citizenship does not bar them from applying for Indian citizenship. However, no such provisions have been employed in case of Muslim immigrants. Millions in India are under the risk of ending up in the detention camps for illegal migrants have been and are currently being built (Pradhan 2020; Hussain 2020). 
It would be intriguing to note that the uncritical, non-analytical and awkward understanding of Hitler in the social science book used for teaching history to Class 9 students, called 'India and the Contemporary World-I', within which topics associated with the discipline of history, political science and economics are clubbed together, the etymological origin of the word 'Nazi' has surprisingly never been explained. Moreover, the word "nationalism" never occurs in the only chapter that is dedicated to the understanding of Hitler and Nazism, titled 'Nazism and the Rise of Hitler'. The context of the Weimar Republic has been abruptly referred to in a rather shallow fashion that almost all NCERT social science textbooks would mimic, and it is here that the word 'nationalist' comes up twice. The first time, it has been used to refer to the opposing side to the supporter of the Weimar Republic as "conservative nationalists". The second time, "militant nationalists" has been used to describe the opposing side to the revolutionaries, wherein both parties are claimed to have been looking for "radical solutions" (NCERT 2005: 52-53). 'India and the Contemporary World-I', consists of little detail on the history of the Holocaust, and rounds it all up in two paragraphs that covers less than half of a single page.

The worst affected has perhaps been Hindi literature itself, wherein every single literary work talking about communal harmony, peace or the Urdu language have been completely exempted. Shyamacharan Dubey's piece (एनसीईआरटी 2015) 'Upbhoktābād Ki Sanskriti (Consumerist Culture)', which is an exploration of modern day consumerism, Chapala Devi's story 'Nānā Sāheb Ki Putri Devi Maina Ko Bhasma Kar Diya Gayā (Nānā Sāheb's daughter Maina was Burned to Ashes)', an intense account of how freedom fighter Nana Saheb's daughter was burned to death by the British colonialists (Ibidem) have been scrapped from the Hindi textbook 'Kșitij'. Freedom fighter and eminent poet Mahadevi Verma's 'Mere Bacpan Ke Din' which is a memoir of her childhood, has been exempted. It mentioned instances of communal harmony, often emphasising on the cross-cultural exchange of traditions 
within Hindu and Muslim families, and how the Urdu and Hindi languages are close to each other, and have often been spoken together (Ibidem 2015). 'Sakhīyāñn' and 'Savad-2' written by Kabīr (Ibidem), who was a fifteenth century mystic saint critical of both Hinduism and Islam, have also been scrapped. 'Sakhīyān', in particular is critical of the idea of both Hinduism and Islam, and their inability to comprehend the true meaning of spirituality as well as the idea of 'Jäti 46 ' persistent mainly within the Hindu community.

Short stories and memoirs inclusive of Mannu Bhandari's 'Ek Kahān̄ Ye Bhı̀' ((एनसीईआरटी 2012) in which she writes about women's struggle for education in India in the mid-twentieth century has been exempted. 'Strī-Sikșā Ke Virodhi Kutkoñ Ka Khandan (The Deconstruction of Stereotypes about Women's Education)' written by Mahavir Prasad Dwivedi (Ibidem: 103-114) and Yatindra Mishra's 'Naubatkhāne Me Ibādat (Rituals of the Orchestra Pit)' about Bismillah Khan's childhood in the culturally rich city of Kaśi (Benares) and his evolution into the great musician who popularised the Shehnai in modern India (Ibidem: 114-125) has been exempted. A philosophical exploration called 'Sanskriti (Culture)' that questions the grey area between Sanskriti and Asanskriti (deculturisation) that is closely associated with the education and disconnect with meaningless relics and traditions that burdens the society (Ibidem: 126-130) written by Bhadant Anand Kausilyayan, a Buddhist monk, has also been dropped out of the syllabus.

Deletion of textbook content has not been the only tool used to Hinduise the adolescent psyche of present day India. Apparently, they have also taken attempts to digitalise the Hindutva propaganda in order to reach out successfully to young adults and students. Juxtaposed with India's unemployment rate, which had been the worst in 45 years in

\footnotetext{
${ }^{46}$ Jātiis a Sanskrit word that is comprehended by ethnographers to signify sub-castes (Bates 1995) or categories of stratification, classified on the basis of profession, which constituted the hierarchically divided Varna system that classified the society into four Varnas - namely Brahmins (priests and scholars), Kșatriyah (warriors and rulers), Vaishyas (businessmen and agriculturalists) and Shudras (providers of skilled and unskilled labour). The internal sub-division of Jatiswere often based on purity and pollution (Dirks 2001).
} 
2019 (India unemployment rate highest in 45 years: Report 2019), desperation within the Indian youth to locate a source of earning might have helped the BJP to accumulate more people within their digital propaganda conglomerates, known as Information Technology (IT) cells. According to the Press Trust of India (PTI), the Uttar Pradesh unit of the BJP set to hire 1.5-2 lakh IT cell employees right after losing the by-poll elections in 2019. Of what has been termed the "Cyber Sēnā"47 by fellow media officials, the vice president of the party in Uttar Pradesh told PTI that the party should be making efforts to link educational institutions to student BJP supporters through the NaMo (abbreviation of Narendra Modi) app and with the help of the IT cells. He also reckoned that in DOIng so, the party could now look forward to an "army" of such individuals, and could be of considerable appeal to first time voters (Dasgupta 2018).

Formalisation of Hierarchy: Upper Casteness, Pedagogy and Pedigree

Since the resources to create and retain academic capital have also remained confined in the hands of the upper castes, the Brahminisation of theory (Figueira 2012), has proliferated and channelised normativity associated with exemption of Dalits and lower castes from the scholarly circles for hundreds of years.

This generational deprivation and the methods of segregation of Dalit students have been formalised within the Hindu societies which gradually ended up crippling entire Dalit communities intellectually, cutting off further possibility of progress in the future. The horror of exemption among, for example, the Mahar caste that Dr. Bhimrao Ramji Ambedkar, a Dalit scholar who is also called the father of the Indian constitution, who later converted to Buddhism belonged to were

\footnotetext{
47 'Sēnā' in Hindi means 'army'. The term Cyber Sēnā has been used by the Vice-President of Uttar Pradesh state unit of BJP, JPS Rathore to refer to "cyber warriors" who are trained to use the Internet and social media in order to mediate Hindu nationalist propaganda, particularly before elections (UP BJP to set up 'cyber sena' of 200,000 social media experts to tap voters 2019).
} 
supposed to tie on their waists a broom at all times in order to erase their own profane footprints (Roychowdhury 2018).

There is no record of untouchable students even in the nineteenth century. There were only some schools that children belonging to middle and lower artisan castes could attend (Nambissan 1996: 1011). Later, it was because of the Christian missionaries that untouchable students finally began attending missionary schools. However, even though it is hard to empirically prove it, the quality of education that these children seemed to have received back then was poor (Richey 1923).

In India, the generic scientist is still largely perceived to be a Brahmin (Thomas 2020: 3). The social reforms that have been introduced more than half a century ago and an abundance of non-Brahmin scientists in the academic space have not been able to de-construct this idea. Since Brahmins had an advantage of earlier access to the Western means of education and the knowledge of the English language, it was the upper castes and Brahmins who benefitted, reshaped and negotiated these new forms of knowledge. They redefined the image of science as Brahmin and Bhadrolok ${ }^{48}$ knowledge, which in turn was reaffirmed as the "authentic biography of science in India" (Thomas 2020: 4). It has been argued whether privatisation of education, that the saffron regimes emphasises on worsens the marginalisation of communities in an intricately stratified society (Patnaik 2017), and might altogether undo the impact of the reservation system (Guru 2000), equivalent to 'Affirmative Action' in the United States (Thomas 2019) adopted by the Indian government in order to encourage development of backward communities.

Branding of 'Dalit scholars' as a differentiated identity alienates him from the rest of the identities in academia and 'Dalithood' is used as

48 ' Bhadrolok in Bengali is a blend word consisting of two separate words - 'Bhadra' meaning 'gentle' and 'Lok meaning people. 'Bhadrolok translates to 'gentleman' and had been used for long to refer to the upper caste elite Bengalis. 
a scale to examine his merit. When N. Sukumar introduced an M. Phil. Course on 'Dalit Politics in India' at Hyderabad Central University (HCU), he was enquired by a senior colleague as to why research agenda was being hijacked from theoretical discourse to praxis. Dalit students, too, are constantly stereotyped within modern day educational institutions, and have to encounter the perpetual quest of proving their merit. They are repeatedly failed, given less marks and often drop out due to consistent humiliation, especially in science and professional courses (Sukumar 2013).

The incorporative and exclusionary presence of "upper casteness" is visible in the admission process procured by the IITs. The process of forging and imposing an entrepreneurial model of the IIT student influenced the possessive investment in upper casteness of the institutions. IIT Bombay particularly represents the ideal types of upper-caste meritocracy that poses a threat to Dalit students pursuing their degrees, who might or might not have availed the benefits of the reservation system. While there would be exceptions where IIT students oppose diasporic claims to meritocracy as expressions of originality or superiority, factions representing communities such as Tamil Brahmins, seek to identify themselves as intellectuals and nation-builders, rooted in the origins of their superior "descent".

Since the 1990s, the expansion of the Joint Entrance Examination (JEE) 49 engineering and architecture coaching industry and the implementation of new quotas for lower castes has produced the need to police the boundaries of merit like never before in order to distinguish the deserving IIT-ian from those who secured a position with the help of the reservation system. The rise of Narendra Modi was simultaneously endorsed by most IIT-ians, inevitable in their endorsement of both BJP's neoliberal capitalism and Modi's authoritarian populism. This

49 A national competitive admission test for engineering and architecture institutions. 
has also led to an escalation in the socio-cultural dominion of politics within the periphery of these campuses (Subramanian 2019: 314).

Even when Dalit and lower-caste students lay claim to merit by choosing to get admission through the general category, which many of them do and are vocal about, they are considered exceptions. The popularity that the BJP seems to have garnered among young adults has resulted in an undercut in terms of gains of lower-caste politics. IIT Madras, among other central government campuses became more open battlegrounds of caste conflict. Ironically, the saffron regime has been known to have committed itself to a systematic mechanism of elimination institutional autonomy to the limits of criminalising student opposition.

The collision between Ambedkar Student's Association (ASA) and the student wing of BJP, called the ABVP, at the Hyderabad Central University (HCU) particularly went a little too intense when the former organised protests against the hanging of Yakub Memon, one of the convicts associated with the Mumbai Terror attacks and the screening of the film 'Muzaffarnagar Baaqi Hai' based upon the 2013 communal riots that played a big role in the BJP's electoral success. After labour minister Bandaru Dattatreya decided to write to the MHRD (Ministry of Human Resource Development) about their "casteist, extremist and anti-national politics", that caused the university authorities to administratively harass members of the ASA, a PhD scholar at the department of Sociology, and Dalit activist Rohith Vemula committed suicide (See: Subramanian 2019).

Around twenty-five students reportedly committed suicide in elite institutions such as the Indian Institute of Technology (IITs), All India Institute of Medical Sciences (AIIMS) and the like in less than a decade. (Rehman 2017; Apparasu 2017; Shantha 2019).

The underrepresentation of the Dalits in terms of positions held within educational institutions in India even after almost a century since some kind of reservation for them had been initiated, proves the 
intricate forms of segregation that they have been subject to for centuries. A problem as deeply rooted as caste based discrimination, is reflected in the collective disadvantages Dalit students and even scholars face within educational institutions, which becomes more pronounced as multiple Dalit students have taken their own lives in the last few decades. The Scheduled Castes (SC) represent only 8.6\%, OBCs represent $30.8 \%$, Scheduled Tribes (ST) account for only a mere $2.27 \%$ of all the teaching positions in higher education institutions in India while 56.8\% belonged to upper castes even when the University Grants Commission (UGC) mandates a $15 \%$ reservation for SCs and 7.5\% for STs (Sharma 2018). Out of the 784 sanctioned faculty posts in eighteen Indian Institute of Management (IIMs), just two are from the ST community, eight from the SC community and twenty seven from the OBC community. Only $9 \%$ of the total faculty of the Indian Institute of Technology (IITs) are represented by the SCs, STs and OBCs combined (Sharma 2019).

The New (Not so) Liberal Education Policy

One of India's most eminent historians, Romila Thapar, was asked to submit her Curriculum Vitae to the Jawaharlal Nehru University (JNU) authorities in order to retain her position of Professor Emeriti. Both Thapar and the JNU teacher-student collectives have been known for intense criticism of the saffron regime, and the government has, since 2014, taken administrative measures to systematically crush student movements within the campus. On the $4^{\text {th }}$ of January, several students and teachers at the university along with student leader Aishe Ghosh was attacked by masked ABVP vigilantes (As it happened: Masked goons strike terror in JNU, none arrested 2020).

A similar attack on students within the Jamia Milia Islamia University campus was attempted by the Delhi Police in December in the wake of the Citizenship Amendment Act 2019 (CAA) protests, which is un- 
constitutional and mandates the creation of National Register of Citizens (NRC), that in turn posits a risk of taking away from non-Hindu citizens their fundamental rights.

Institutions like JNU and Jadavpur University students along with noted faculty members have been known to actively protest the implementation of the laws that allow absolute privatisation of public funded higher education institutions in India. They have consistently opted for solidarity with protests in Shaheen Bagh and Park Circus, led by Muslim women against the implementation of the CAA. A PhD student of Sociology at Jamia Milia University, Safoora Zargar, who was arrested on the claims that she had organised protests against the CAA, and had to serve around three months in prison even though she was pregnant (Pandey 2020) under the Unlawful Activities Prevention Act (UAPA).

Jamia students Meeran Haider, Shifa-ur-Rehman, and Asif Iqbal Tanha, a third year B.A. student of the Persian language, JNU student and activist Umar Khalid, feminist activists Devangana Kalita and Natasha Narwal (Sarkar 2020) have all been arrested on charges associated with the Delhi riots this year which happened when BJP MP Kapil Mishra allegedly provoked a number of Hindus at Mawjpur Chowk to consolidate against the ones who had been protesting against CAA at the Jaffrabad blockade (Chauhan 2020).

Further, DU Professor Hany Babu Musaliyarveettil Tharayil in connection with the 2018 Elgar Parishad case, along with eleven other activists and authors, have been arrested since then. All of these operations have been solely conducted by the central government, often without informing the state government about the arrests (Dahat 2020). Delhi University Professor Apoorvanand has been questioned and harassed by the Delhi police because of the support that he had offered to the anti-CAA protest movements (Taskin 2020).

By June 2018 a draft Act to establish a new body and dismantle the University Grants Commission (UGC) was made public for consultation: the Higher Education Commission of India (HECI) Act 2018. This 
proposed that the regulatory and standard-setting role of the UGC would be handed over to a new body called the Higher Education Commission of India (HECI) that wipes clean the vestiges of academic, institutional and financial autonomy of higher education institutions. This unified higher education body sets to transcend the responsibility of education related policymaking directly to administrators and/or industrialists. A collaborative body called the Higher Education Financing Agency (HEFA) might have been set up to move grants from loans, and hence encourage private sector investment backed by public spending (Gupta, Chattarji 2019). Several scholars, politicians and even Dalit Bahujan intellectuals have debated the legitimacy behind implementation of HECI, and have expressed fear on the immediate correlation HECI seems to be sharing with the ongoing process of Saffronisation.

Although UGC has been known to be largely bureaucratic and has had its drawbacks, at the very least it was a body governed solely by academicians, who have had the necessary experience and training in the field of education. The National Education Policy (2020) guidelines issued by the MHRD, a culmination of freshly issued policies demands to reduce the content of each discipline "to its core essentials". It would be very dubious for one to imagine exactly what could be deemed essential by an authoritarian, fundamental regime that seeks to unrecognise the very existence of those identities that seem to conflict with its method of operation and profitmaking. It also claims that Sanskrit is an "important modern language" that "possesses a classical literature that is greater in volume than that of Latin and Greek put together".

Although diluting the prominent lines of demarcation between the disciplines associated with the sciences, arts and commerce sections is a good decision given that the education system all over the world is functioning the same way, and the attempt to modernise the modules and provide some very essential relaxation in terms of choices of what would be the equivalent of A-levels in middle and high school is commendable, the abrupt adoption of measures to privatise education in 
a country that has faced and manufactured discrimination historically, the overall paradigm shift of the education sector embedded in a Saffronised India might be a step forward towards further Hinduisation of the very scope of higher education, one that posits the risk of marginalisation on an exponential plane that would affect more than minority communities and a confined, distinct category of educational curricula.

\section{References}

Amnesty International. (2019, June 30). Halt the Hate. An interactive website that documents reports of alleged hate crimes in India. https://amnesty.org.in/wp-content/uploads/2019/10/Halt-TheHate-KeyFindings-Amnesty-International-India-1.pdf

Ambikar, R. (2008). Educating the Nation: The Right Way to Citizenship in India. UCVF Research Review, 2(1):, 114-128. http://journals.ufv.ca/rr/RR21/article-PDFs/ambikar.pdf

Ambikar, R. (2012). Embodying the Enemy: Muslim Students in Right Wing Hindu Schools. Anthropology News, 53(7), 52-53. https://www.academia.edu/1968525/Embodying_the_Enemy Anderson, W. (1972). The Rashtriya Swayamsevak Sangh: I: Early Concerns. Economic and Political Weekly, 7(11), 589+591-597. http://www.jstor.org/stable/4361126

Antidote to Self-Oblivion. (2012, October 22). Vision and Mission. Rashtriya Swayamsevak Sangh. Retrieved, September 02, 2020, from https://www.rss.org//Encyc/2012/10/22/rss-vision-and-mission.html

Apparasu, S.R. (2017, March 27). JNU 'suicide': Dalit Scholar was Rohith Vemula's Friend at Hyderabad University. Hindustan Times. https://www.hindustantimes.com/delhi/jnu-suicide-dalit-scholarwas-rohith-vemula-s-friend-at-hyderabad-university/storyBa5TSwFTXgmIyQKnkWGWoL.html 
As it happened: Masked goons strike terror in JNU, none arrested. (2020, January 05). The Hindu. https://www.thehindu.com/news/ cities/Delhi/live-updates-jnu-students-attackedinside-campus-byabvp-activists/article30486246.ece

Awards and Honours received by Chancellor Amma. (Undated). Amrita Vishwa Vidyapeetham Official Website. Retrieved, November 14, 2020, https://www.amrita.edu/amma/awards-honors

Bakaya, A. (2004). Lessons from Kurukshetra: RSS Project in Education. [In:] A. Vaugier-Chatterjee (Eds.), Education and Democracy in India (pp. 27-54). New Delhi: Manohar Publishers and French Research Institute in India.

Baker, D.E.U. (1979). Changing Political Leadership in an Indian province: the Central Provinces and Berar, 1919-1939. New York: Oxford University Press.

Bapu, P. (2012). Hindu Mahasabha in Colonial North India, 19151930. London: Routledge.

Basu, D. (2019a). Dominance of Majoritarian Politics and Hate Crimes against Religious Minorities in India, 2009-2018. UMass Amherst Economics Working Papers, 272, 1-83. https://scholarworks.umass.edu/cgi/viewcontent.cgi?article=1274\&context=econ_workingpaper

Basu, D. (2019b, October 17). UMass Economist Finds Hate Crimes Against Religious Minorities in India Increased 300\% Following Rise of Hindu Nationalist Party BJP. News Archive, UMass Amherst. https://www.umass.edu/newsoffice/article/umass-economist-findshate-crimes-against

Basu, T., Datta, P., Sarkar, S., Sarkar, T., Sen, S. (1993). Khaki Shorts Saffron Flags: A Critique of the Hindu Right. New Delhi: Orient Longman.

Bates, C. (1995). Race, Caste and Tribe in Central India: The Early Origins of Indian Anthropometry. Edinburgh Papers in South Asian 
Studies, 3, 2-35. http://www.csas.ed.ac.uk/__data/assets/pdf_file/ oo05/38426/BATES_RaceCaste_and_Tribe.pdf

Bhatia, A. (2015). The 'saffronisation' of India and Contemporary Political ideology. World Englishes, 39(4), 568-580. DOI: 10.1111/weng.12494 Bose, P. (2008). Hindutva Abroad: The California Textbook Controversy. The Global South, 2(1), 11-34. DOI: 10.2979/GSO.2008.2.1.11 Casolari, M. (2000). Hindutva's Foreign Tie-Up in the 1930s: Archival Evidence. Economic and Political Weekly, 35(4), 218-228. DOI: $10.2307 / 4408848$

Casolari, M. (2002). Role of Benares in Constructing Political Hindu Identity. Economic and Political Weekly, 37(15), 1413-1420. DOI:10.2307/4411986

Casolari, M. (2011). In the Shade of the Swastika: The Ambiguous Relationship between Indian Nationalism and Nazi-Fascism. Bologna: I Libri di Imil.

Chauhan, M. (2010). Gender Construction through Religious Narrative in Saraswati Siśu Mandir School. Proceedings of the Indian History Congress, 71, 1189-1195.

Chauhan, M. (2013). Socialization in a Patriarchal Regime: An Analysis of Saraswati Shishu Mandir School Text-books. Proceedings of the Indian History Congress, 74, 988-992.

Chauhan, N. (2020, February 28). Delhi riots: Face-off between Bhim Army, CAA backers a trigger. Hindustan Times. https://www.hindustantimes.com/delhi-news/delhi-riots-face-off-between-bhimarmy-caa-backers-a-trigger/story-iYMqbEZjVNcXY3kzjxw8OO.html

Committee of the Central Advisory Board of Education. (2005). Regulatory Mechanisms for Textbooks and Parallel Textbooks Taught In Schools outside the Government System. Ministry of Human Resource Development (MHRD), Government of India. https://www.education.gov.in/sites/upload_files/mhrd/files/document-reports/textbooks.pdf 
Cotteril, S., Sidanius, J., Bhardwa, A., Kumar, V. (2014). Ideological Support for the Indian Caste System: Social Dominance Orientation, Right-Wing Authoritarianism and Karma. Journal of Social and Political Psychology, 98-115. DOI:10.5964/jspp.v2i1.171

Dahat, P. (2020, July 28). NIA Arrests DU Professor Hany Babu in Elgar Parishad Case. Huffington Post. https://www.huffingtonpost.in/entry/nia-arrests-du-professor-hany-babu-in-elgar-parishad-case_in_5f202af6c5b69fd47311ed28

Dasgupta, P. (2018, June 13). After Bypoll Losses, BJP Is Training 2 Lakh 'Cyber Sena' For Its IT Cell In Uttar Pradesh. Huffington Post. https://www.huffingtonpost.in/2018/o6/13/after-bypoll-lossesbjp-is-training-2-lakh-cyber-sena-for-its-it-cell-in-uttar-pradesh_a_23457592/

Delaney, B. (2019, April 18). Hugging the hugging Saint: Amma made others cry but it was different for me. The Guardian. https://www. theguardian.com/commentisfree/2019/apr/19/hugging-the-hugging-saint-amma-made-others-cry-but-it-was-different-for-me

Deshpande, R. (2002, September 30). Supreme Court ruling vindicates HRD Minister M.M. Joshi's stand on school curriculum. India Today. https://www.indiatoday.in/magazine/nation/story/20020930supreme-court-ruling-vindicates-hrd-minister-m.m.-joshi-standon-school-curriculum-796208-2002-09-30

Dirks, B.N. (2001). Castes of Mind: Colonialism and the Making of Modern India. Princeton and Oxford: Princeton University Press.

Dixit, N. (2013, 18 January). Holier Than Cow: Wisdom on women from a Rashtra Sevika Sangh camp. Outlook India. https://www.outlookindia.com/magazine/story/holier-than-cow/283593

Figueira, D.M. (2012). Aryans and the Brahminization of Theory: Identity Politics East and West, Past and Present. Comparative Studies of South Asia, Africa and the Middle East, 32(3), 511-522. DOI: 10.1215/1089201X-1891534 
Forensic Analysis Finds Same Gun Used to Kill Gauri Lankesh and M.M. Kalburgi (2017, September 14). The Wire. https://thewire.in/uncategorised/forensic-analysis-finds-gunused-kill-gauri-lankesh-m-m-kalburgi

Froerer, P. (2007a). 'Disciplining the Saffron Way: Moral Education and the Hindu Rashtra'. Modern Asian Studies, 41(5), 1033-1071. DOI:10.1017/Soo26749Xo6002587

Froerer, P. (2007b). Religious Division and Social Conflict: The Emergence of Hindu Nationalism in Rural India. London and New York: Routledge.

Golwalkar, M.S. (1939). We or Our Nationhood Defined. Nagpur: Bharat Publications Nagpur.

Goyal, D.R. (1979). Rashtriya Swayamsevak Sangh. Delhi: Radha Krishna Prakashan.

Gupta, S., Chattarji, S. (2019). Protests, repression, restructuring: contemplating Indian higher education in 2018. Postcolonial Studies, 22(1), 117-130. DOI: 10.1080/13688790.2019.1568175

Guru, G. (2000). Dalits from Margin to Margin. India International Centre Quarterly, 27(2), 111-116.

Hardiman, D. (2007). Purifying the nation: The Arya Samaj in Gujarat 1895-1930. The Indian Economic and Social History Review, 44(1), 41-65. DOI:10.1177/001946460604400103

Hussain, T. (2020, January 02). 'How is it human?': India's largest detention centre almost ready. Al Jazeera. https://www.aljazeera.com/ news/2020/1/2/how-is-it-human-indias-largest-detention-centrealmost-ready

India unemployment rate highest in 45years: Report. (2019, 31 January). Al Jazeera. https://www.aljazeera.com/economy/2019/01/31/indiaunemployment-rate-highest-in-45-years-report/

Iwanek, K. (2015). The Textbook of Chanakya's Pupils. Vidya Bharati and Its Gauravśālī Bharat Textbook in Uttarakhand. Archiv Orientální, 83(2), 255-280. 
Jaffrelot, C. (1996). The Hindu Nationalist Movement in India. New York: Columbia University Press.

Jaffrelot, C. (2008a). Hindu Nationalism and the Social Welfare Strategy. Seva Bharati as an Education Agency. [In:] The Sangh Parivar: A Reader (pp. 211-224). New Delhi: Oxford University Press.

Jaffrelot, C. (2008b). Hindu Nationalism and the (Not So Easy) Art of Being Outraged: The Ram Setu Controversy. South Asia Multidisciplinary Academic Journal, 2, 1-17. DOI:10.400o/samaj.1372 Jha, D.N. (2001). The Myth of the Holy Cow. New Delhi: Matrix Books. Lal, V. (2006). The History of History, Politics and Scholarship in Modern India. New Delhi: Oxford University Press.

Manjrekar, N. (2011). Ideals of Hindu girlhood: Reading Vidya Bharati's Balika Shikshan. Childhood, 18(3), 350-366.

Mathur, S. (2008). The Everyday Life of Hindu Nationalism. Gurgaon: Three Essays Collective.

Monier-Williams, M. (1872). A Sanskrit-English Dictionary: Etymologically and philologically arranged with special reference to Cognate Indo-European languages. Oxford: The Clarendon Press.

Meadowcroft, K. (2006). The All-India Hindu Mahasabha, untouchable politics, and 'denationalising' conversions: the Moonje-Ambedkar Pact. South Asia: Journal of South Asian Studies, 29(1), 9-41. DOI:10.1080/00856400600550781

M.N., P. (2016, March 01). Controversial student activists turn India's universities into ideological battlegrounds. LA Times. https://www.latimes.com/world/asia/la-fg-india-student-activists20160301-story.html

Nambissan, G.B. (1996). Equity in Education? Schooling of Dalit Children in India. Economic and Political Weekly, 31(16/17), 1011-1024. Nandini. (2020, July 09). CBSE syllabus: Secularism, Nationalism, GST, foreign relations among chapters dropped, full list here. Hindustan Times. https://www.hindustantimes.com/education/cbse-syllabus- 
secularism-nationalism-gst-foreign-relations-among-chaptersdropped-full-list-here/story-QhATDgnKWooWHAa6jyTnyH.html NCERT. (2005). India and the Contemporary World - I. Delhi: National Council of Education Research and Training.

NCERT. (2006). Indian Constitution at Work. Delhi: National Council of Education Research and Training.

NCERT. (2007). Themes in World History. New Delhi: National Council of Education Research and Training.

NCERT. (2011). Themes in Indian History Part - I, II and III. New Delhi: National Council of Education Research and Training.

NCERT. (2013a). Contemporary India - II. New Delhi: National Council of Education Research and Training.

NCERT. (2013b). Democratic Politics - II. New Delhi: National Council of Education Research and Training.

NCERT. (2013c). India and the Contemporary World - II. New Delhi: National Council of Education Research and NCERT. (2006). Indian Constitution at Work. New Delhi: National Council of Education Research and Training.

NCERT. (2014a). Contemporary India - I. New Delhi: National Council of Education Research and Training.

NCERT. (2014b). Political Theory. New Delhi: National Council of Education Research and Training.

NCERT. (2015). Democratic Politics - I. New Delhi: National Council of Education Research and Training.

एनसीईआरटी. (2012). Kșitij Bhag 2. New Delhi: National Council of Education Research and Training

एनसीईआरटी. (2015). Kșitij Bhag 1. New Delhi: National Council of Education Research and Training.

National Education Policy. (2020). Ministry of Human Resource Development (MHRD), Government of India. https://www.education.gov. in/sites/upload_files/mhrd/files/NEP_Final_English_o.pdf 
Interview of NV62EX and NOB6E3 conducted by Titas Biswas. Oral History Summaries used after obtaining special permission from The 1947 Partition Archive.

Pandey, G. (2020, May 12). India Coronavirus: Pregnant student Safoora Zargar at risk in jail. BBC News. https://www.bbc.com/ news/world-asia-india-52608589

Pansare murder Chargesheet: 'Teen saw Sanatan member on crime spot'. (2015, December 15). The Indian Express. https://indianexpress.com/article/cities/pune/pansare-murder-chargesheet-arrested-sanatan-member-was-on-crime-spot-cops/

Patnaik, P. (2017). Caste, Community and Belonging: The Indian Case. Social Scientist, 45(1/2), 73-79.

Pradhan, B. (2020, February 26). Millions in India Could End Up in Modi's New Detention Camps. Bloomberg. https://www.bloomberg.com/features/2020-modi-india-detention-camps/

Puniyani, R. (2003). Beef Eating: Strangulating History. Countercurrents. https://www.countercurrents.org/comm-puniyani150803.htm

Rajeshwari, B. (2007). Pedagogy and the Construction of Communal Identity in Children: The Case of Shishu Mandirs in Gujarat. Child Rights and You. https://www.cry.org/resources/pdf/NCRRF/B.Rajeshwari_2007_Report.pdf

Ramanathan, K. (2020, January 21). In India What We Are Seeing Are Symptoms of Fascism: Noam Chomsky. Countercurrents. https://countercurrents.org/2020/o1/in-india-what-we-are-seeing-is-the-symptoms-of-fascism-noam-chomsky/

Roychowdhury, A. (2018, January 03). Battle of Koregaon: Why the Dalits hate Peshwas and celebrate this British 'victory'. Indian Express. https://indianexpress.com/article/research/battle-of-koregaon-dalits-mahar-maratha-peshwa-maharashtra-protests-5010172/

Rehman, S. (2017, February 14). Rohith is the 23rd Dalit student suicide in institutes like AIIMS and IITs. Catch News. 
http://www.catchnews.com/national-news/blood-on-books-rohith-vemula-s-is-the-23rd-dalit-student-suicide-in-under-a-decade-bandaru-dattatreya-abvp-bjp-rahul-gandhi-thorat-committeecaste-1453210563.html

Richey, J.A. (1923). Progress of Education in India: Eighth Quinquennial Review Vol I. Calcutta: Superintendent Government Printing India.

RSS: The Mission. (2012, October 22). Vision and Mission. Rashtriya Swayamsevak Sangh. Retrieved September 01, 2020, https://www.rss.org//Encyc/2012/10/22/rss-vision-and-mission.html

Sarkar, T. (2005). Educating the Children of Hindu Rashtra. [In:] C. Jaffrelot (Eds.), The Sangh Parivar: A Reader (pp. 197-206). New Delhi: Oxford University Press.

Sarkar, S. (2020, November 21). Delhi riots: Student-activist Gulfisha Fatima granted bail. Hindustan Times. https://www.hindustantimes.com/delhi-news/delhi-riots-student-activist-gulfishafatima-granted-bail/story-UqsLO2noxJfnovVTttSdwJ.html

Sen, S. (2015, September 22). No strong evidence against Sanatan Sanstha, says BJP leader RK Singh. News18. https://www. news18.com/news/politics/no-strong-evidence-against-sanatansanstha-says-bjp-leader-rk-singh-110836o.html

Shantha, S. (2019, September 27). Four Months After Payal Tadvi's Death, Family Claims Her Belongings From Hospital. The Wire. https://thewire.in/caste/four-months-after-payal-tadvis-deathfamily-claims-her-belongings-from-hospital

Sharma, K. (2018, July 27). Nearly 57\% of India's teaching faculty belong to general category, STs Least represented. The Print. https://theprint.in/india/governance/57-of-indias-teaching-faculty-belong-to-general-category-sts-least-represented/89546 
Sharma, K. (2019, February 13). Diversity deficit in IIMs, IITs - just 23 STs and 157 SCs in 9,640 Faculty Posts. The Print. https://theprint.in/india/education/diversity-deficit-in-iims-iits-just-23-stsand-157-scs-in-9640-faculty-posts/191246/

Shirer, W.L. (1961). The Rise and Fall of the Third Reich: A History of Nazi Germany. New York, NY: Rosetta Books LLC.

Singh, Divyesh. (2015, October 06). Sanatan Sanstha proposes workshops for teachers to promote 'good behaviour'. Mumbai Mirror. https://mumbaimirror.indiatimes.com/mumbai/other/sanatansanstha-proposes-workshops-for-teachers-to-promote-good-behaviour/articleshow/49237538.cms

Subramanian, A. (2019). The Caste of Merit: Engineering Education in India. Cambridge, MA and London: Harvard University Press. Sukumar, N. (2013). Quota's Children: The Perils of Getting Educated. [in:] Beyond Inclusion: The Practice of Equal Access in Indian Higher Education. (Eds.) Deshpande, S., Zacharias, U. (pp. 205221). New Delhi: Routledge.

Sundar, N. (2004). Teaching to Hate: RSS' Pedagogical Programme. Economic and Political Weekly, 39 (16), 1605-1612.

Sundar, N. (2005). Teaching to Hate: The Hindu Right's Pedagogical Program. Revolution and Pedagogy: Interdisciplinary and Transnational Perspectives on Educational Foundations. [In:] E.T. Ewing (Eds.), Revolution and Pedagogy: Interdisciplinary and Transnational Perspectives on Educational Foundations (pp. 195-218). New York and Hampshire: Palgrave Macmillan.

Taskin, B. (2020, August 04). DU professor Apoorvanand questioned by police for 3 hrs over Delhi riots, his phone seized. The Print. https://theprint.in/india/du-professor-apoorvanand-questionedby-police-for-3-hrs-over-delhi-riots-his-phone-seized/474552/ 
Tewary, A. (2018, February 12). RSS can prepare an Army within three days, says Mohan Bhagwat. The Hindu. https://www.thehindu.com/news/national/other-states/rss-can-prepare-an-armywithin-3-days-mohan-bhagwat/article22727198.ece

Theatre blast convicts get 10 years in jail. (2011, August 31). The Hindu. https://www.thehindu.com/news/national/other-states/theatreblast-convicts-get-10-years-in-jail/article2412137.ece

Thomas, R. (2020, February 08). Brahmins as Scientists and Science as Brahmins' Calling: Caste in an Indian Scientific Research Institute. Public Understanding of Science, 29(3), 306-318. DOI: 10.1177/0963662520903690

Thomas, S. (2019). Difference and Dissent in the Neoliberal University: Relational Geographies of Race, Caste, and Violence. Discourse: Studies in the Cultural Politics of Education, 1-13. DOI: 10.1080/01596306.2019.1655636

UP BJP to set up 'cyber sena' of 20o,ooo social media experts to tap voters. (2019, November 19). Press Trust of India (PTI). https://www.business-standard.com/article/politics/up-bjp-to-setup-cyber-sena-of-200-ooo-social-media-experts-to-tap-voters118061200671_1.html

Vidya Bharati Selected as Vanguard Member by the International Development Innovation Alliance IDIA for its Million Lives Club. (2020, April 03). Press Trust of India (PTI). https://www.theweek. in/wire-updates/business/2019/10/24/pwr6--vidya\%2obharati.html

Visweswaran, K., Witzel, M., Manjrenkar, N., Bhog. D, and Chakravarti, U. (2009). The Hindutva View of History: Rewriting Textbooks in India and the United States. Georgetown Journal of International Affairs, 10(1), 101-112.

Weinberger-Thomas, C. (1999). Ashes of Immortality: Widow-burning in India. Chicago and London: University of Chicago Press. 
Yadav, V.K. (2016, June 14). Sanatan Sanstha Wanted To Raise Army of 15,000 To Target 'Anti-Hindus'. Mid-Day. https://www.midday.com/articles/sanatan-sanstha-wanted-to-raise-army-of1500o-to-target-anti-hindus/17332199 